\title{
ORDE E DESORDE NO ESPAZO FORESTAL
}

\author{
Juan Picos Martín
}

Escola de Enxeñaría Forestal de Pontevedra Universidade de Vigo 



\section{UNHA NOVA XERACIÓN DE LUMES (?)}

A evolución do réxime de incendios está a xerar episodios que difiren en duración, intensidade e período de retorno do que viñemos considerando normal con referencia aos anos 60, 70, 80 e 90 do século XX.

Segundo a clasificación dinámica de xeracións de incendios reflectida na táboa 1, a nivel global existe unha tendencia á aparición de graves episodios de incendios en escalas cada vez maiores.

Táboa 1. Descrición das xeracións de incendios segundo Castellnou

\begin{tabular}{|c|c|c|}
\hline $1^{a}$ xeración & Continuidade (C) & $\begin{array}{l}\text { A paisaxe rural descontinua empeza a abandonarse. A continuidade } \\
\text { de combustible permite ás chamas crear incendios grandes. }\end{array}$ \\
\hline $2^{a}$ xeración & $\mathrm{C}+$ velocidade $(\mathrm{V})$ & $\begin{array}{l}\text { Esta paisaxe segue sen xestión e a acumulación de combustible } \\
\text { permite un aumento da velocidade de propagación das frontes. }\end{array}$ \\
\hline $3^{a}$ xeración & $\mathrm{C}+\mathrm{V}+$ intensidade $(\mathrm{I})$ & $\begin{array}{l}\text { O paso do tempo segue engadindo carga de combustible. } \\
\text { As frontes son máis intensas e permiten xerar incendios convectivos, } \\
\text { con ambiente de lume e focos secundarios masivos. O ataque directo } \\
\text { falla xa nestas situacións, como falla tamén a prevención clásica } \\
\text { de devasa ou cortalumes. }\end{array}$ \\
\hline $4^{a}$ xeración & $\begin{array}{l}\mathrm{C}+\mathrm{V}+\mathrm{I}+ \\
\text { Grandes Incendios } \\
\text { Forestais na interface } \\
(\mathrm{IF})\end{array}$ & $\begin{array}{l}\text { Os incendios propáganse na interface urbano-forestal. O problema xa } \\
\text { non é un problema forestal, é unha emerxencia de protección civil. } \\
\text { As prioridades veñen dominadas pola defensa. Pérdese a iniciativa. } \\
\text { Risco de colapso do sistema de resposta a emerxencias. }\end{array}$ \\
\hline $5^{a}$ xeración & $\begin{array}{l}\mathrm{C}+\mathrm{V}+\mathrm{I}+\mathrm{IF}+ \\
\text { simultaneidade de GIF } \\
(\mathrm{S})\end{array}$ & $\begin{array}{l}\text { Episodios de simultaneidade de incendios de } 3^{a} \text { ou } 4^{a} \text { xeración } \\
\text { cando se dan condicións estruturais de seca sobre as que se solapa } \\
\text { unha conxuntura meteorolóxica extrema. Colapso do sistema local e } \\
\text { rexional de resposta a emerxencias. A cooperación interaxencia ou } \\
\text { interrexional é unha necesidade. }\end{array}$ \\
\hline $6^{a}$ xeración & $\begin{array}{l}\mathrm{C}+\mathrm{V}+\mathrm{I}+\mathrm{IF}+\mathrm{S}+ \\
\text { cambio climático }(\mathrm{CC})\end{array}$ & $\begin{array}{l}\text { Situación de tormentas de lume. O cambio climático xera áreas } \\
\text { forestais sometidas a un enorme estrés e dispoñibles para queimar. } \\
\text { A intensidade liberada nestes casos permite ao incendio dominar as } \\
\text { condicións meteorolóxicas da súa contorna, co cal crea condicións } \\
\text { de tormenta e propagacións extremas. }\end{array}$ \\
\hline
\end{tabular}

Fonte: Castellnou e Miralles (2008), Picos et al. (2018) 
$\mathrm{Na}$ actualidade, o patrón de incendios implica lumes que presentan continuidade e velocidade en zonas até agora esencialmente rurais e que comezan a incrementar a súa intensidade, a súa capacidade convectiva e a emisión de focos secundarios, aspecto de especial gravidade en áreas de poboamento disperso. Este patrón está evolucionando con rapidez cara a situacións de grandes incendios con afección múltiple na interface urbano-forestal. Isto erosiona a capacidade de resposta do operativo contra incendios, que ten que adoptar estratexias defensivas, coa nefasta consecuencia que iso implica: deixar de atacar no espazo forestal. Esta circunstancia determinouse como relevante e crítica nas distintas análises dos episodios de incendios sufridos en 2017 tanto en Portugal como en Galicia.

Esta evolución do patrón de incendios forestais ten a súa raíz na xestión da paisaxe, na escalada na continuidade e carga de combustible propiciada polo abandono das actividades rurais, principalmente agricultura, gandaría e xestión forestal. Con todo, o cambio climático súmase, a maiores, ao favorecer unhas tempadas de risco máis longas, uns períodos de seca máis prolongados e unha maior e máis rápida acumulación e posta en dispoñibilidade do combustible.

Esta complexa realidade dos incendios no oeste peninsular é a que máis se está agravando nos últimos anos. De feito, dos grandes incendios de máis de 10000 ha nos pasados 15 anos na Península Ibérica, máis do 80 \% déronse nesta zona xeográfica (táboa 2).

Ademais, o denominado "paradoxo da extinción» (Castellnou e Rifa 2007) formúlase como un proceso mediante o que a crecente presión de extinción implica unha proporción cada vez maior de conatos, pola rápida intervención, pero aqueles que non son controlados queiman grandes superficies con intensidades cada vez superiores. Isto quere dicir que, cantos máis medios e máis presión aplicamos sobre o lume, mellor se controlan os incendios, pero a acumulación de biomasa e a súa continuidade comportan que os poucos que escapan a este control se fagan máis grandes e destrutivos e baseen a súa evolución nunha crecente carga de combustible.

É precisamente nas zonas de invernos húmidos e temperados onde o cambio climático está a sumar máis puntos na evolución do problema, en esencia porque é onde se acumula de maneira máis rápida e constante a carga de combustible e, durante situacións de aridez extrema longas, entra en dispoñibilidade. 
Táboa 2. Incendios de máis de 10000 ha na Península Ibérica nos últimos 15 anos

\begin{tabular}{|c|c|c|c|}
\hline Incendio & Ano & Superficie (ha) & Área xeográfica \\
\hline Várzea dos Cavaleiros & 2017 & 33693 & Oeste peninsular \\
\hline Pedrógão Grande & 2017 & 28913 & Oeste peninsular \\
\hline Cortes de Pallás & 2012 & 28079 & Levante \\
\hline Minas de Riotinto & 2004 & 28065 & Oeste peninsular \\
\hline Monchique & 2018 & 26763 & Suroeste peninsular \\
\hline Cachopo & 2012 & 24843 & Oeste peninsular \\
\hline Ulme & 2003 & 22190 & Oeste peninsular \\
\hline Janarde & 2016 & 21909 & Oeste peninsular \\
\hline Belver & 2003 & 20087 & Oeste peninsular \\
\hline Andilla & 2012 & 20025 & Levante \\
\hline San Matías & 2003 & 17869 & Oeste peninsular \\
\hline Álvares & 2017 & 17520 & Oeste peninsular \\
\hline Alferce & 2003 & 17213 & Oeste peninsular \\
\hline Alte & 2004 & 14508 & Oeste peninsular \\
\hline Ferradosa & 2013 & 14136 & Oeste peninsular \\
\hline Sobreira Formosa & 2003 & 13500 & Oeste peninsular \\
\hline Cáceres & 2003 & 13450 & Oeste peninsular \\
\hline Marmelete & 2003 & 13144 & Oeste peninsular \\
\hline Riba de Saelices & 2005 & 12732 & Sistema Ibérico \\
\hline Silves & 2003 & 12656 & Oeste peninsular \\
\hline Castrocontrigo & 2012 & 11950 & Oeste peninsular \\
\hline Vidual & 2005 & 11706 & Oeste peninsular \\
\hline Isna & 2003 & 11300 & Oeste peninsular \\
\hline La Jonquera & 2012 & 10578 & Levante \\
\hline Ermida & 2003 & 10500 & Oeste peninsular \\
\hline Encinedo & 2017 & 10315 & Oeste peninsular \\
\hline Robledano & 2005 & 10021 & Oeste peninsular \\
\hline Complexo Verín-Viana-A Limia & 2005 & 14486 & Oeste peninsular \\
\hline Complexo Galicia costa 2006 & 2006 & $>70000$ & Oeste peninsular \\
\hline Complexo Pontevedra 2017 & 2017 & $>20000$ & Oeste peninsular \\
\hline
\end{tabular}

Fonte: Elaboración propia a partir de MAPAMA, Fernandes et al. (2016) e Picos et al. (2018) 
O principal risco futuro consiste en que se sufra no oeste e noroeste peninsulares a mesma evolución do comportamento dos incendios vivida entre 1994 e 2009 no leste da Península. Isto significaría pasar estruturalmente de episodios de incendios simultáneos de primeira e segunda xeración a episodios de quinta xeración. Existen indicios desta tendencia que viñeron sendo constatados polos servizos de defensa contra incendios forestais durante os últimos quince anos. Ademais, non se debe ignorar o feito de que en zonas interiores de Portugal e Galicia se teñan observado algúns episodios de incendios de terceira xeración. É aquí onde se atopa o potencial, materializado en 2017, dos incendios de sexta xeración. Como xa se dixo, é o primeiro lugar en Europa onde se evidencia este tipo de incendio, e é moi relevante que fose no atlántico peninsular húmido e non no mediterráneo seco. Isto apunta ao papel da rápida acumulación de combustible fino, até supor elevadas cargas, que eventualmente as condicións meteorolóxicas adversas fan dispoñibles. Este fenómeno non se dá, con esa intensidade, no mediterráneo máis árido.

\section{QUE FACER?}

\subsection{Aproximación á prevención}

O estudo dos grandes incendios do 2017, en especial os acontecidos en Portugal, conclúe a chegada da tipoloxía de incendios de sexta xeración. Estes caracterízanse, basicamente, por seren incendios que conseguen xerar grandes cantidades de enerxía e incrementos da velocidade de propagación en frontes extensas. Isto convérteos en incendios letais para a poboación, os servizos de defensa contra incendios, as infraestruturas e os intereses da sociedade en xeral.

$\mathrm{O}$ incendio forestal hai tempo que deixou de ser un problema exclusivo duns servizos de extinción que necesitan consumir cada vez máis recursos durante unha campaña cada vez máis longa. Os sucesivos incrementos orzamentarios e aumentos de medios e recursos anualmente na loita contra os incendios forestais non producen melloras significativas na redución da superficie queimada. Por outra banda, a efectividade dos medios de extinción está próxima ao seu límite e as posibilidades de continuar reducindo o impacto dos incendios forestais 
pasan inevitablemente pola mellora das estratexias preventivas eficientes que reduzan os riscos (Oliveira 2016).

Ademais de se efectuaren cambios nas estratexias de protección civil e nos dispositivos de defensa contra incendios, no que atinxe ás políticas sobre o territorio rural deberíase facer especial fincapé na xestión da carga de combustible. O obxectivo radica en evitar incendios de terceira xeración, situacións de incendios convectivos alleos á capacidade de extinción, e reducir, no posible, a súa evolución cara a episodios extremos de quinta e sexta xeración.

Cando un grande incendio forestal afecta áreas extensas que presentan unha alta carga de combustible procedente dun abandono da agricultura e a silvicultura, acaba homoxeneizando aínda máis o territorio. Se ao incendio lle sucede un maior abandono das actividades e a recuperación da vexetación volve incrementar a carga de combustible, o risco de sufrir outro grande incendio é maior.

Para anticiparse ás situacións de perturbación causadas polo lume, a acción silvícola é fundamental e, en xeral, terá sempre certa compoñente preventiva no seu obxectivo de xestión e mellora das masas forestais.

Pola contra, existe determinada corrente de opinión que preconiza a non-intervención nos procesos ecolóxicos, para deixar que a natureza actúe por si mesma. Con todo, parece máis razoable actuar previndo que os danos se produzan ou para que, no caso de ocorreren, a súa acción resulte minimizada e, mediante a persistencia e a multifuncionalidade, poidan satisfacerse as lexítimas demandas dos propietarios forestais e da sociedade.

\subsection{Os combustibles forestais}

O lume é unha reacción química de oxidación exotérmica, na cal se libera a enerxía contida nas ligazóns dos compostos orgánicos. Para que se produza o lume necesítanse os tres elementos que forman o chamado triángulo do lume: combustible, comburente (osíxeno) e calor (iniciadora do proceso de combustión e precisa para mantelo).

Os combustibles son calquera substancia ou composto susceptible de acenderse e manter un proceso de combustión. Nos ecosistemas terrestres o combustible adoitan ser os compostos orgánicos (principalmente celulosa e lignina) producidos na fotosíntese. Por tanto, cando se fala de combustibles forestais 
estase a considerar toda a materia orgánica que se atopa nos montes en condicións de dispoñibilidade para a combustión nun potencial incendio. Esta categoría comprende a biomasa de plantas vivas, a súa follaxe, os seus talos, as súas ramas e as súas raíces; a necromasa -restos de tecidos mortos-, que inclúe árbores mortas en pé ou caídas, cepos, outros restos leñosos e follas que se atopan na manta de descomposición sobre o chan, así como a materia orgánica que forma parte do solo.

O tipo de material combustible e as súas características físicas e químicas, a cantidade «carga» del, a súa superficie de exposición, o seu grao de compactidade e a súa distribución espacial nos planos horizontal e vertical son os factores que determinarán o comportamento do lume.

Os estudos de combustión de vexetación no laboratorio mostran que existen diferenzas no que se denomina «inflamabilidade» das plantas. Este concepto, que non ten unha definición científica estándar, basicamente se refire a un indicador da «facilidade de arder ante unha fonte de calor determinada», elaborado a partir da medición correspondente a unha mostra estandarizada de tempo para a ignición, a rapidez da combustión e a enerxía desprendida. Cos valores característicos para cada especie (ou parte característica de cada especie), adóitase efectuar a clasificación en máis ou menos inflamables.

Os diferentes estudos levados a cabo a escala de poboamento forestal e paisaxe veñen evidenciando que os estudos realizados a escala de planta ofrecen unha visión moi limitada do comportamento do lume nas condicións en que se desenvolve no monte.

Aínda que existen distintos traballos sobre a selectividade de tipos de usos, vexetación e utilización do solo polos incendios, as relacións atopadas non implican que a mera composición da masa forestal sexa o factor primordial e exclusivo da maior ou menor afección polos incendios forestais.

Os combustibles son complexos en moi alto grao nas súas características e interaccións. Normalmente, mesmo por riba da súa composición específica, a estrutura da masa é o principal condicionante da súa inflamabilidade a escala de poboamento forestal e paisaxe. Esa estrutura complexa clasifícase no que se denomina «modelos de combustible», que dependen tanto da especie como, sobre todo, da cantidade de biomasa dispoñible para o lume e da forma en que se organiza. 
A variación espacial do complexo de combustibles está asociada á da cuberta vexetal e é determinada pola influencia de factores como o clima, as características fisiográficas, os chans e as perturbacións pasadas, que deron lugar a un mosaico de vexetación que se atopa en distintas etapas de desenvolvemento.

O termo combustibilidade aplícase, en silvicultura preventiva e extinción de incendios forestais, para definir a facilidade coa que un incendio podería progresar nunha determinada masa forestal ao recibir calor por radiación ou convección, ou ambas. A combustibilidade das masas dependerá da humidade, tamaño, disposición e abundancia dos seus combustibles.

O contido de humidade varía temporalmente en relación cos cambios de sucesión e estación da vexetación e coa variación nas condicións meteorolóxicas. En ausencia de choiva, a humidade relativa do aire é o factor que máis inflúe na humidade dos combustibles mortos. Normalmente xeran maior risco os materiais mortos ou secos que os materiais vivos ou verdes. Os combustibles verdes teñen un contido de auga de arredor do $70 \%$ en peso cando non hai seca e, en condicións extremas, poden baixar a cifras de arredor do $30 \%$. Os combustibles secos ou mortos poden conter até un $50 \%$ de humidade en saturación pero chegar a secarse até valores próximos ao $3 \%$. Por baixo do $10 \%$ xa se considera que existe alto risco (Vélez 2000).

Os combustibles finos expoñen unha maior superficie específica, o que facilita a perda de humidade e, no momento do incendio, a oxidación, a combustión total e a liberación rápida de enerxía, que será a que sosteña o lume. Así, canto máis finos sexan os combustibles, será esperable unha maior velocidade de avance e propagación. Este é o caso dos herbais, as matogueiras, as ramiñas cubertas de agullas secas e as ramas finas do arboredo, máis abundantes preto do chan nas clases de idade novas e cando hai restos de talla ou tratamentos silvícolas. Son denominados combustibles rápidos porque teñen gran facilidade para cambiar a súa humidade (desecándose ou incorporándoa).

Os incendios comezan normalmente na superficie e propáganse pola continuidade horizontal do material combustible, avivados por outras condicións favorables como o vento ou a pendente. Se alcanza suficiente intensidade, a calor, transmitida fundamentalmente por convección e axudada polos chamados «combustibles de escaleira» (arbustos ou árbores pequenas e troncos de árbores mortas, así como brións, liques e plantas epífitas), provoca que as ramas inferiores e a follaxe das árbores entren en ignición. 
Estes incendios denomínanse incendios de copas e poden pola súa vez clasificarse en pasivos, activos e independentes do lume de superficie. Nun incendio de copas pasivo, as copas arden individualmente e non prospera a propagación do lume a través dos elementos finos do combustible no dosel. Por outra banda, no incendio de copas activo, o lume propágase de forma continua polo estrato aéreo, pero necesita para manterse, en todo momento, da calor xerada polo incendio de superficie. Por último, nun incendio de copas independente do lume de superficie, o lume de copas avanza de maneira independente empuxado polo vento e a maior velocidade que o de superficie, que queda atrasado. A existencia dos dous últimos tipos de incendios de copas require, ademais, velocidades de vento elevadas e dispoñibilidade de combustible dunha densidade aparente significativamente superior á densidade real.

$\mathrm{Na}$ evolución dun incendio de superficie a outro de copas activo, a velocidade de propagación do lume sofre un incremento súbito que chega a duplicar a velocidade de avance do lume superficial, o que pode significar que se multiplique por catro o tamaño da área queimada no mesmo período. Isto supón un problema engadido para as persoas involucradas na extinción, posto que os incendios de copas presentan un nivel de comportamento do lume que usualmente impide as accións de ataque directo e, no caso dos lumes de copas independentes, aumentan de forma radical os perigos de entalamento.

Por outra banda, a materia orgánica do chan polo xeral retén humidade por máis tempo e atópase en atmosferas de escasa achega de osíxeno, o cal fai que exista unha maior dificultade para que entre en ignición. Cando isto ocorre, xeralmente en solos moi ricos en materia orgánica, pode dar lugar a incendios subterráneos, que se propagan con lentitude, son moi difíciles de extinguir, xeran unha gran cantidade de calor e provocan unha alta gravidade ao cambiaren dun xeito significativo as características dos solos.

Despois de analizarmos todas estas características, definiremos «combustible dispoñible» ou «combustible dispoñible para arder» como aquel que, nun determinado momento, posúe un tamaño e unha humidade que permiten a combustión da biomasa ao verse afectada esta polas chamas ou a enerxía irradiada pola fronte do incendio.

A mellor maneira de comprobar que non toda a biomasa vexetal dun ecosistema terrestre é combustible dispoñible é observar que, tras o paso dun incendio, 
aínda que desaparece boa parte do sotobosque, a follada e a frouma do chan, así como as follas e ramiñas terminais dos piñeiros, hai unha fracción significativa que non se consome, como troncos, ramas grosas e unha parte das ramas finas.

\subsection{Principios da silvicultura preventiva}

Segundo Vélez (2000), a silvicultura preventiva é un conxunto de regras que se inclúen dentro da silvicultura xeral co propósito de conseguir estruturas de masa con menor grao de combustibilidade, é dicir, con maior resistencia á propagación do lume.

Os obxectivos da silvicultura preventiva de incendios son os seguintes:

- Diminuír o número total de sinistros, previndo ou evitando, na medida do posible, a ignición ou o inicio do lume.

- Impedir ou dificultar a propagación daqueles incendios cuxo inicio non se puido evitar.

- Minorar os danos, especialmente a superficie percorrida, no caso de que o incendio se produza.

- Facilitar os labores de extinción dos incendios que non foi posible evitar e darlles seguridade. Este obxectivo, o máis importante, cítase en último lugar por ser consecuencia dos dous anteriores.

Basicamente, a aplicación da silvicultura preventiva pódese realizar en dous niveis territoriais: así, diferéncianse estratexias a escala local (parcela, monte ou grupo de montes) e a escala comarcal.

Deixando á parte, por excederen o ámbito deste documento, a redución do número e risco de ignicións e as axudas á protección de bens e ao combate, as principais accións previstas pola silvicultura preventiva son as citadas a seguir:

- Actuacións sobre o combustible forestal.

- Creación de descontinuidades na masa e nas infraestruturas lineais.

- Prevención a escala comarcal. Modificación do combustible a escala de paisaxe.

Actuando sobre os combustibles búscase influír na intensidade do lume e na súa velocidade de propagación horizontal e vertical, aumentar a súa previsibilidade e, por conseguinte, diminuír a área queimada e aumentar a eficiencia e seguridade dos medios de extinción. Indirectamente, tamén se acaba diminuíndo a potencial gravidade do incendio e, por iso, o seu impacto ambiental. 
Os principios xerais da xestión dos combustibles e da silvicultura preventiva son coñecidos, con todo, pola elevada complexidade do comportamento e dos efectos dos incendios, especialmente en ambientes meteorolóxicos extremos; aínda existen incertezas e aínda é limitada a comprensión dos efectos que a dita xestión ten no comportamento do lume.

Segundo Pyne et al. (1996), as tres estratexias principais de acción sobre o combustible forestal na silvicultura preventiva son redución, conversión e illamento. Noutras palabras, buscaranse cambios na cantidade de combustible, na súa estrutura, na súa tipoloxía e na xeración de descontinuidades na masa que se quere protexer.

O cambio na tipoloxía de combustible -estratexia de conversión- consiste na substitución da vexetación existente por outra que reduza a magnitude das variables de comportamento do lume (velocidade de propagación, intensidade lineal da fronte de chamas etc.) ou limite a súa propagación.

Este efecto moderador é alegado con frecuencia, por exemplo, no caso das masas de frondosas caducifolias, a pesar de que, en moitas ocasións, máis que ser o mero froito das características intrínsecas destas especies, o efecto vén moito máis condicionado polo ambiente asociado habitualmente a este tipo de formacións, menos ventoso e máis fresco e húmido, en especial nos momentos de secas prolongadas.

Para influir sobre a cantidade e dispoñibilidade do combustible, deberanse reducir os combustibles de superficie (follada, frouma, restos leñosos e vexetación de matogueira viva), co fin de limitar a intensidade potencial do lume de superficie, facilitar o seu control por parte dos medios de extinción e dificultar o lume de copas.

A cantidade de combustible é denominada «carga de combustible» e adóitase medir en toneladas por hectárea; nela é habitual que se faga distinción das distintas fraccións do combustible.

Na ilustración 1 amósase un exemplo (adaptado de Fernandes [2009]) da relación entre a intensidade da fronte do incendio e a carga de combustible fino para as distintas situacións de perigo de incendio forestal (medido segundo o FFDI ou índice de McArthur). Indícanse, ademais, os límites de intensidade cos que é posible facer fronte ao incendio en función dos medios utilizados. Pódese apreciar que, para índices de perigo baixos, o límite en ataque directo ao 
lume (mesmo co uso de maquinaria e medios aéreos) non se supera con cargas de $30 \mathrm{t} / \mathrm{ha}$, pero que, en situacións de risco medio, alto e moi alto, estes valores límite son 28, 18 e 13 t/ha, respectivamente. Cando o perigo é extremo, bastan 8 t/ha de combustible fino para superar intensidades que están moi por riba da capacidade de extinción.

Esta é a razón pola que reducir as cantidades de combustible, en especial aquelas fraccións que ofrecen maior dispoñibilidade para arder, como son os combustibles finos e mortos, é imprescindible para abordar a prevención da propagación dos incendios dunha maneira efectiva.

Para alén de actuar na mera eliminación, resulta decisivo promover, mediante a aplicación das técnicas xerais da silvicultura, que a masa se atope nas mellores condicións de vigor e sanidade. Unha masa sa e vigorosa presenta, en proporción, unha menor cantidade de biomasa fina e morta.

Complementariamente, é moi importante proceder á eliminación ou tratamento dos restos producidos en operacións silvícolas e aproveitamentos. De preferencia, executarase ese proceso por trituración ou estelado porque o usual é que as achas queden depositadas no chan, ardan con gran dificultade e atrasen ademais a invasión do chan pola matogueira e as herbáceas (ilustración 1).

Ademais da conversión e a redución, é importantísimo acometer accións sobre a estrutura espacial do combustible. Dise que hai continuidade horizontal nun estrato de combustible cando non existen grandes espazos libres de combustible que impidan o avance do lume en ningunha dirección. A continuidade vertical implica a existencia dunha ponte entre os combustibles dos distintos estratos e, por tanto, favorece a transformación do lume de superficie en lume de copas.

As accións máis relevantes sobre a estrutura do combustible son as seguintes:

- Distanciar a base das copas do chan (principalmente mediante podas e clareos) e eliminar os combustibles de transición que establezan continuidades con aquelas, co fin de minimizar a posibilidade de desenvolvemento vertical de lume.

- Rarear a masa, normalmente polo baixo, para diminuír a densidade aparente da cuberta de copas e así dificultar a propagación do lume entre árbores contiguas.

- Conservar as árbores máis grandes da masa. As árbores de maiores dimensións adoitan ser máis resistentes ao lume, xa que habitualmente teñen as 
Ilustración 1. Relación entre intensidade da fronte do incendio, índices de perigo, carga de combustible e capacidades de extinción en masas de eucalipto

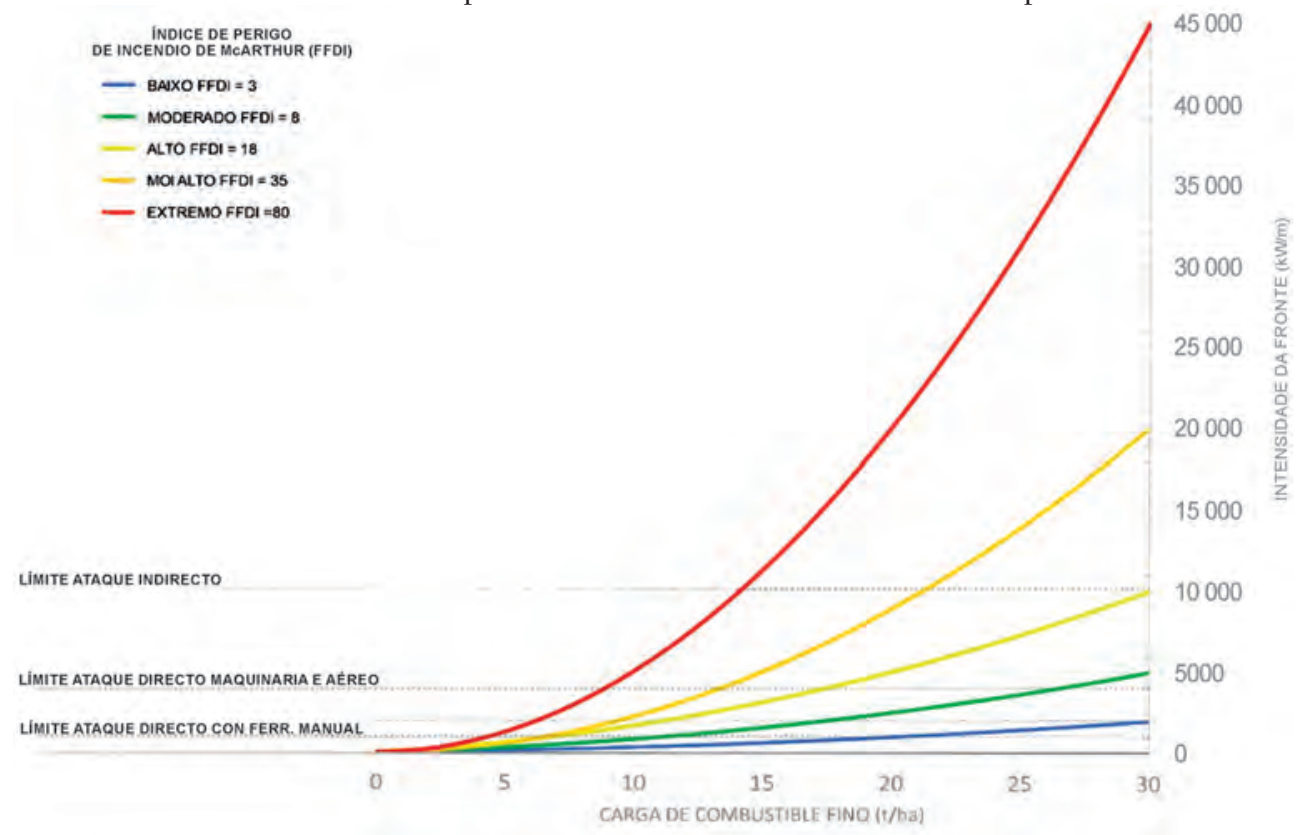

ADAPTADO DE FERNANDES (2009)

copas máis altas e a cortiza máis grosa. Así mesmo, poderían axudar á rexeneración natural da masa tras un incendio.

- O resultado das accións combinadas que acaban de citarse será independizar as copas do arboredo respecto do chan, acentuando a descontinuidade vertical, e modificar no monte a disposición do tipo de combustible de maior facilidade de ignición. A consecuencia será que, en caso de incendio, predomine o lume de superficie, de menor velocidade de avance, de maior facilidade e seguridade na extinción e de menor dano para o arboredo.

Outra das ferramentas de xestión preventiva é a creación de descontinuidades na masa. Esta estratexia do illamento consiste en romper a continuidade horizontal das masas forestais, eliminando ou reducindo a vexetación, para compartimentalas mediante faixas de anchura variable ou crear mosaicos. 
En xeral, pódese distinguir entre unha estratexia baseada en interrupcións ou tratamentos lineais en forma de faixas e devasas e unha estratexia que se basea en tratamentos en áreas máis extensas.

As devasas son espazos alongados, cunha anchura de entre 20 e 30 metros, nos que se elimina todo tipo de vexetación, deixando frecuentemente o chan mineral ao descuberto. Adoitan disporse sobre liñas artificiais, como camiños ou límites entre montes; sobre liñas naturais, como liñas de máxima pendente coincidentes coa separación creada por interfluvios, e sobre liñas de cumes. Debido a que acostuman ser chamadas "cortalumes», en moitas ocasións existe a expectativa de que consigan deter ou diminuír dun xeito significativo a progresión dos incendios, cousa que só ocorre nos de baixa intensidade ou nos flancos. Principalmente, as redes de devasas teñen como obxectivo dar seguridade aos equipos terrestres de extinción, aumentar a súa eficacia e posibilitar a aplicación de fogo técnico en contralumes e queimas de ensanche.

Os inconvenientes das devasas son os danos polo escoamento nas que se trazan en liña de máxima pendente, a necesidade de conservación periódica para evitar a rexeneración natural sobre elas e o negativo efecto paisaxístico.

Por outra parte, as áreas de defensa contra incendios son superficies relativamente amplas, cunha anchura de entre 40 e 100 metros, nas que se actúa para modificar o modelo de combustible cara a modelos de menor combustibilidade e velocidade de propagación. O obxectivo destas infraestruturas é aumentar a capacidade de intervención dos medios de ataque terrestres ao aumentar a súa seguridade, eficacia e produtividade.

Normalmente execútanse rareos, clareos e podas altas, acompañados de rozas. Poden manterse con pastoreo ou con reiteración de rozas. Outra alternativa de conservación é a queima prescrita. Cabe complementalas con devasas auxiliares e tamén adoitan aproveitar a existencia de pradarías, rasos ou rochedos.

Hai que destacar que todas as actuacións vistas até agora terían como escala a da unidade de xestión forestal, monte ou conxunto de montes. En xeral, a prevención estrutural non segue unha política transversal, encarando o territorio como un todo, e adoita considerarse como a suma de accións a escalas de xestión forestal que son executadas por diferentes axentes e organismos. A pesar de poder ser eficaz nos casos máis habituais de incendios, esta falta de accións xeneralizadas en territorios máis amplos non permite unha adecuada defensa fronte 
aos denominados grandes incendios forestais. Segundo Oliveira (2016), polo mesmo motivo de que estes «consomen" paisaxe, deben ser enfrontados mediante unha prevención exposta e levada a cabo á mesma escala.

As liñas xerais da prevención a nivel comarcal son as seguintes:

- Estruturar a vexetación en mosaicos, de entre decenas e centos de hectáreas. Trátase de evitar a continuidade en grandes extensións de igual tipo de masa. É evidente que este obxectivo non é sempre viable, sobre todo cando as condicións estacionais ou a realidade actual das masas impoñen unha monotonía que non é posible ou conveniente modificar.

- As masas mixtas, particularmente aquelas nas que hai presenza de especies brotadoras, amosan maior resiliencia por unha mellor rexeneración natural tras os incendios. Resulta, pois, conveniente, desde este punto de vista, inducir, en lugares axeitados, subpisos de frondosas en masas regulares de coníferas, especialmente se estas son artificiais. Tal intervención ten que ser coidadosa no que atinxe a non empeorar a estrutura vertical da masa en áreas moi extensas.

- Sobre as marxes de ríos e arroios, aproveitando as condicións de humidade, tratarase de manter ou inducir masas de especies ripícolas e de menor inflamabilidade. Estas formacións de chopos, salgueiros, bidueiros, freixos ou ameneiros dificultan o avance do lume, sempre que se manteñan ben rozadas. Pola contra, as valgadas de abundante matogueira son zonas de alto risco para a extinción e de gran velocidade de avance do lume.

- Manter e inducir, con regulacións adecuadas, certo pastoreo nos montes. Como xa se viu, a función do gando, controlando o desenvolvemento do sotobosque e consumindo combustibles de pequeno tamaño, confire ás masas unha menor combustibilidade relativa. Para conseguir con maior eficacia estes obxectivos, débense introducir altas cargas durante breves períodos de tempo, inducindo a consunción de todo o combustible potencial e evitando que o gando desprece as especies menos palatables, que non poucas veces resultan ser as máis inflamables.

- Desenvolver unhas redes complexas de compartimentación do territorio. Estas redes tradicionalmente se adoitan subdividir en varias escalas: redes primarias, executadas en terreos forestais e a unha escala inframunicipal, e redes secundarias, de nivel municipal ou local, que, atendendo a outras 
características do terreo e do risco de incendios, poden levarse a cabo aos lados de infraestruturas lineais (estrada, pista, ferrocarril, liñas eléctricas etc.) ou ao redor de núcleos urbanos, edificacións, polígonos industriais e zonas de recreo integradas nun espazo forestal, onde se reduce a carga de combustible, total ou parcialmente.

- Desenvolver mosaicos de parcelas de xestión de combustible, ou, na terminoloxía dos GRAF da Generalitat de Catalunya, puntos estratéxicos de xestión (PEG), que poidan dificultar a propagación e, sobre todo, constituír oportunidades de extinción. Nestes lugares, situados no interior dos compartimentos definidos polas redes primaria e secundaria, procédese á xestión de varios estratos de combustible e á diversificación da estrutura e composición das formacións forestais e de matogueira. A localización e dimensión dependen dunha análise de incendios pasados ou de simulacións. Aquelas superficies queimadas en anos anteriores, afloramentos rochosos, amplos espazos agrícolas e outros espazos libres de combustible poden, igualmente, constituír mosaicos.

\section{ONDE FACELO?}

\subsection{O espazo forestal}

O monte é unha realidade territorial complexa, integrante doutra realidade complexa como é o propio medio rural galego. Este, ademais da súa importancia económica e social, ten funcións medioambientais que se recoñecen e se acrecentan progresivamente. En particular, unha parte significativa dos montes galegos están incluídos na Rede galega de espazos naturais protexidos, desempeñan unha importante tarefa na conservación dos sistemas hidrolóxicos ou acollen numerosas e senlleiras mostras do patrimonio arqueolóxico ou cultural. Alén diso, as masas arborizadas e os solos forestais son un reservatorio básico de carbono que os converte en piares fundamentais para a loita contra o cambio climático.

A propia «delimitación» do que se entende por espazo forestal non é un asunto trivial. A definición legal do «monte ou terreo forestal» (ver cadro 1) é, no seu comezo, aparentemente simple, pero dun xeito gradual, a base de explicitar a súa 
casuística, unha serie de intervalos temporais para a súa consideración como tal e as súas relacións con outras lexislacións, como a urbanística, acaba resultando dunha complexidade excesiva. Esta complexidade definitoria e normativa terá efecto, como veremos, na propia «ordenación» do espazo.

Cadro 1. Definición de monte segundo a Lei 7/2012, do 28 de xuño, de montes de Galicia (o destacado é noso)

Artigo 2. Concepto de monte ou terreo forestal

1. Para os efectos desta lei, enténdese por monte ou terreo forestal todo terreo en que vexetan especies forestais arbóreas, arbustivas, de matogueira ou herbáceas, sexa espontaneamente ou que procedan de sementeira ou plantación, que cumpran ou poidan cumprir funcións ambientais, protectoras, produtoras, culturais, paisaxísticas, sociais ou recreativas.

Teñen tamén a consideración de monte ou terreo forestal:

a) Os terreos ermos, os rochedos e os areais.

b) As construcións e as infraestruturas destinadas a servizo do monte en que se localizan, así como os equipamentos e as infraestruturas de uso sociorrecreativo.

c) Os terreos de antigo uso agrícola e con polo menos dez anos continuados de abandono, sempre que adquirisen sinais inequívocos do seu carácter forestal, cando formen parte de superficies continuas de polo menos 5 hectáreas, agás que se trate de terreos que estean incluídos con ese fin nun banco de terras ou instrumento semellante.

d) Todo terreo que, sen reunir as características descritas anteriormente, se adscriba coa finalidade de ser repoboado ou transformado á actividade forestal, de conformidade coa normativa aplicable.

e) Os enclaves forestais en terreos agrícolas coa superficie mínima de 5 hectáreas, a non ser que se compoñan os ditos enclaves de masas de especies forestais de frondosas do anexo 1 cunha idade media de polo menos dez anos, diminuíndose, para estes casos, a dita superficie mínima ata 1 hectárea.

2. Non teñen a consideración de monte ou terreo forestal:

a) O solo urbano e o solo de núcleo rural.

b) 0 solo urbanizable delimitado, coas excepcións sinaladas na disposición transitoria quinta.

c) Os terreos de dominio público, agás os que integran o dominio público forestal.

d) Os terreos rústicos de protección ordinaria destinados a cultivo agrícola.

e) Os terreos rústicos de especial protección agropecuaria, sen prexuízo do establecido no apartado seguinte deste artigo e no artigo 61 desta lei.

3. En todas as categorías de solos rústicos de especial protección os aproveitamentos forestais rexeranse polo disposto nesta lei en todo aquilo en que non se lles aplique a súa normativa específica.

(Redacción segundo a modificación dos apartados 2.e) e 3 polo artigo 49 da Lei 2/2017, do 8 de febreiro).

\subsection{A ordenación do territorio}

En Galicia, o territorio é o resultado de milleiros de anos de intervención humana que transformou unha pretérita paisaxe natural nunha paisaxe funcional. En tempos pasados a velocidade do cambio (aínda que supuxese transformacións 
radicais) era lenta e, deste xeito, propiciouse a asimilación da paisaxe funcional como unha paisaxe cultural. Actualmente as mudanzas prodúcense cunha grande intensidade e rapidez e, na maioría dos casos, sen integración entre elas. A irrupción do transporte motorizado de persoas e mercancías rachou cun modelo tradicional de hábitat diseminado, pero estruturado de acordo cunha rede de unidades produtivas rurais e cidades como centros de intercambio. No entanto, o principal factor de alteración no patrón territorial non se explica só pola fuxida da aldea cara á cidade, senón tamén pola segunda onda de fuxida das cidades cara ás súas periferias polo fracaso no seu crecemento ordenado e a carestía da vivenda en períodos especulativos. Desta forma, as vilas e cidades foron substituídas por conglomerados construídos con tipoloxías e usos diversos, cunha dificultade de dotación de servizos, nunha matriz fractal de natureza pseudorrural onde algúns dos usos se manteñen, pero a maior parte dos residentes xa non gardan relación funcional coas parcelas non edificadas, o que as converte nun mero reservatorio de espazo edificable.

A análise das mudanzas na utilización da terra entre 1985 e 2005 realizada por Corbelle e Crecente (2014) indica que, nese período, o 43,2 \% da superficie total de Galicia cambiou de uso. Ademais, esa porcentaxe de mudanza foi moi constante nas distintas categorías; é dicir, Galicia mantivo unha matriz de aproximadamente o $50 \%$ estable en cada unha das tipoloxías, mentres que a outra metade mudou ao resto das clases (táboas 3 e 4). Aínda que con diferenzas territoriais, nese período aumentou a superficie urbanizada e o arboredo, diminuíu a ocupada pola agricultura e a gandaría e grandes áreas do territorio quedaron abandonadas. A comparación con datos da capacidade produtiva do chan revela que, en xeral, a urbanización e o mantemento do uso agrícola ou gandeiro tiveron lugar principalmente nas terras de maior calidade produtiva, mentres que a forestación se concentrou en terras de calidade intermedia e o abandono afectou ás de peores características.

A expansión da denominada interface urbano-forestal (ou urbano-rural segundo outros autores), asociada á crecente dispersión do sistema de asentamentos e á progresión da vexetación natural, constitúe unha dinámica territorial preocupante. Este proceso de cambio «turbulento» do uso do solo supón un dos elementos que máis está a contribuír a incrementar a vulnerabilidade fronte a un tipo de incendio que pode non só alcanzar as áreas edificadas, senón tamén pro- 
Táboa 3. Matriz de cambio de uso do solo en Galicia (1985-2005) segundo Corbelle e Crecente (2014)

\begin{tabular}{|l|r|r|r|r|r|r|}
\hline & \multicolumn{5}{|c|}{ Clase do ano 2005 } & Total de \\
\cline { 1 - 5 } Clase do ano 1985 & 1. S. ag. & 2. Mat. & 3. Arb. fr. & 4. Arb. pr. & 5. Impr. & $\mathbf{1 9 8 5}$ \\
\hline 1. Superficie agrícola & 520505 & 106571 & 74814 & 158253 & 67834 & 927977 \\
\hline 2. Matogueira & 130901 & 504851 & 90623 & 235249 & 17554 & 979178 \\
\hline 3. Arboredo: frondosas & 25047 & 22244 & 68797 & 32349 & 2482 & 150919 \\
\hline 4. Arboredo: produtor & 94931 & 131497 & 32516 & 551264 & 23745 & 833953 \\
\hline 5. Improdutivo & 10690 & 12146 & 2401 & 8031 & 34298 & 67566 \\
\hline Total de 2005 & 782074 & 777309 & 269151 & 985146 & 145913 & 2959593 \\
\hline
\end{tabular}

Táboa 4. Superficie estable ao cambio de uso do solo en Galicia (1985-2005) segundo Corbelle e Crecente (2014)

\begin{tabular}{|l|c|c|c|}
\hline & $\mathbf{2 0 0 5}$ & \multicolumn{2}{|c|}{ Superficie estable (1985-2005) } \\
\hline Superficie agrícola & 927977 ha & 520505 ha & $56,10 \%$ \\
\hline Matogueira & 979178 ha & 504851 ha & $51,60 \%$ \\
\hline Arboredo: frondosas & 150919 ha & 68797 ha & $45,60 \%$ \\
\hline Arboredo: produtor & 833953 ha & 551264 ha & $66,10 \%$ \\
\hline Improdutivo & 67566 ha & 34298 ha & $50,80 \%$ \\
\hline Total & 2959593 ha & 1679715 ha & $56,80 \%$ \\
\hline
\end{tabular}

pagarse no seu interior. Esta extensión da ameaza a bens e persoas provoca, ademais dun incremento do risco, unha crecente complexidade nos labores de prevención e, sobre todo, de extinción, xa que fai que xurdan uns problemas específicos, distintos nun grao substancial dos provocados polos incendios puramente forestais ou urbanos.

Chas-Amil et al. (2013) observaron nas súas análises que o $69,7 \%$ das edificacións de Galicia se sitúan en espazos clasificables como interface urbano-forestal/rural. Alén diso, de entre estas áreas, aquelas que contan cunha maior frecuencia de ignicións (chegando a máis dun punto por quilómetro cadrado) son aquelas que presentan aglomerados densos ou maior fragmentación forestal, ou ambos. 
Despois de máis de trinta anos de autonomía galega, a ordenación do territorio mantense como unha materia pendente. Un repaso do estado de desenvolvemento e aprobación de distintas figuras de ordenamento urbanístico indica que menos dun terzo dos concellos galegos teñen o seu planeamento adaptado á LOUG e 40 non dispoñen de planeamento (táboa 5).

Táboa 5. Figuras de planeamento urbanístico nos concellos de Galicia

\begin{tabular}{|l|c|}
\hline PXOM adaptado á LOUG & 96 \\
\hline PXOM/POMR adaptado á Lei 1/1997 & 44 \\
\hline PXOM/POMR ao abeiro da D. T. 3a da LOUG & 22 \\
\hline NSP/PXOU anterior á LASGA & 14 \\
\hline NSP/PXOU adaptado á LASGA até a Lei 7/1995 & 63 \\
\hline NSP/PXOM entre a Lei 7/1995 e a Lei 1/1997 & 20 \\
\hline Simple delimitación do solo urbano & 16 \\
\hline Sen planeamento & 40 \\
\hline & Total de concellos \\
\hline
\end{tabular}

Fonte: SIOTUGA (http://www.planeamentourbanistico.xunta.es/siotuga) [última consulta: decembro, 2018]

A conxuntura de parálise da actividade construtiva ocorrida tras a crise de 2008 non foi aproveitada para cambiar o modelo de consumo incontrolado e especulativo de espazo. Tampouco foi alterado o modelo de financiamento municipal, para que deixase de ser totalmente dependente dos ingresos xerados pola actividade urbanística. A non-existencia destas correccións fai que a aparente recuperación económica dos últimos anos veña a reincidir nos mesmos problemas que foron expostos en parágrafos precedentes.

A manifesta dificultade amosada durante décadas para planificar o crecemento ordenado do urbanismo galego fai dubidar de que os instrumentos inspirados na mesma filosofía, a da planificación urbanística, sexan axeitados para traballar na ordenación do espazo rural e, en particular, do forestal.

Gondar (2007) denuncia que, tradicionalmente, as zonas urbanas consideraron o rural como «o espazo baleiro entre grandes núcleos urbanos cunha especie de xardineiros provisionais que o coidan mentres non se precisen máis metros para edificar» e «o receptor resignado (e gratuíto) das infraestruturas que non 
caben ou non interesan no mundo urbano». Do mesmo xeito, coa coartada de aquelas sentírense ameazadas polos novos incendios forestais, non se pode só mirar ás áreas rurais desde as cidades co fin de establecer unha maraña de restricións sobre o seu desenvolvemento sen pretender transferir recursos ou compensacións.

\subsection{A ordenación e a planificación forestais}

\subsubsection{Concepto e orixe da ordenación forestal}

Enrique Mackay, en 1944, baseándose na definición que deu a finais do século pasado Lucas de Olazábal, escribiu que «ordenar» un monte é «organizalo conforme ás leis económicas, sen infrinxir as biolóxicas que a investigación silvícola e a epidométrica revelan». O mesmo Mackay establecía catro condicións básicas para a ordenación: persistencia, rendemento sostido, máximo rendemento (optimización das utilidades) e a "condición de extensión suficiente», da que se falará máis adiante.

Deste xeito, os métodos clásicos de ordenación buscan, ademais de, obviamente, garantir a tal persistencia e posible mellora das masas forestais, obter un rendemento sostido da produción do monte mediante a consecución dunha determinada estrutura global das formas principais de masa, establecida conforme a uns modelos teóricos dados de organización do monte, ou mediante a aproximación á dita estrutura. Estes métodos, en xeral caracterizados por unha enorme rixidez, non resistiron o paso do tempo e o cambio dos tempos, a pesar «da beleza estática e da seguridade infantil que proporcionaban ao proporen un sistema formado por cousas claras e ben delimitadas» (Garitacelaya 2008).

O mesmo concepto de ordenación veu experimentando unha profunda mudanza, grazas á experiencia acumulada de máis dun século desde a súa concepción e aplicación, con discutible grao de implantación, a pesar de loables e contadas excepcións.

É un lugar común que, á hora de falar de xestión forestal, se empregue como indicador a superficie sometida a «plans de xestión aprobados pola Administración» (en sentido amplo). En España, tomando como referencia o propio Ministerio competente, só existen proxectos de ordenación ou instrumentos de plani- 
ficación análogos para o $28 \%$ da superficie forestal pública española e para o $6,5 \%$ da privada. Estas modestas cifras serían moi inferiores se só fosen consideradas aquelas superficies que teñen os seus plans minimamente actualizados ou vixentes ou onde eses documentos se empregan como guía de xestión efectiva.

Isto fai dubidar, como moi pouco, de se existen disfuncións entre o seu deseño, obxectivos, custos, utilidade e repercusións legais, para moitas das realidades forestais (tipo de producións, tamaño da unidade de xestión ou natureza da propiedade). En palabras de Garitacelaya (2008):

Aínda quedan [...] montes nos que se aplicou [a ordenación] na prehistoria do coñecemento da xestión forestal, e nos que contra vento e marea, á conta de grandes sacrificios e altos custos, se manteñen como museos vivos, ou como monumentos á dificultade de moitos forestais de adaptárense aos tempos e ao avance dos coñecementos.

\section{Converxendo con estes argumentos, Saura (2009) afirmaba que}

na práctica os métodos de ordenación clásicos, ou a mesma necesidade de sequera seleccionar ou identificar un deles en concreto, [esmorecen] nestes momentos en moitas zonas do noso país. Os xestores atópanse con que en ocasións ningún deles é especialmente adecuado para os obxectivos perseguidos na ordenación dun monte ou espazo forestal concreto, ou que, sen resultaren inadecuados, a elección dun ou doutro resulta ser practicamente indiferente para os efectos das medidas que adoptar dentro do plan especial, que é o que terá vixencia e aplicación real no monte. Esta progresiva maior importancia do plan especial foi deixando as previsións do plan xeral como puramente indicativas e con cada vez menor relevancia [...], proceso acentuado polas tendencias actuais de aplicar unha xestión adaptativa [...], até chegar a deixar en moitos casos a elección do método de ordenación como un requisito puramente formal sen impacto real na planificación e xestión real que necesita o monte de acordo cos estándares actuais.

Segundo Garitacelaya (2008),

[P]ara un forestal español do século XX o estudo e a elección de cal dos métodos de ordenación debía aplicar era unha cuestión importante. Pero nos últimos vinte anos a súa supervivencia debeuse máis á inercia do tempo e á dificultade do alumeamento dos 
novos paradigmas. Non evolucionaron os métodos senón a mesma concepción da ordenación, que acabou por acantoar a «cuestión do método». Os «métodos de ordenación» deixaron de ter relevancia, malia que aínda atopen un lugar e unha autoridade [...].

Esta tendencia (ou necesidade nalgúns casos) de non decantarse por ningún método de ordenación concreto preestablecido nin axustar a xestión nun monte a el deu en chamarse, nos últimos anos, o «método de ordenación por poboamentos forestais», cando en realidade vén a consistir (permítase a simplificación) en elaborar un plan de xestión sen buscar nin adoptar ningún método nin estrutura de monte globais concretos, aplicando en cada poboamento forestal, cantón ou unidade de xestión que se diferencie os tratamentos considerados máis convenientes atendendo ás necesidades e condicións de cada un deles. Como González et al. (2006) expoñen,

na ordenación por poboamentos forestais, a planificación a longo prazo é xeral e orientativa, esta baséase na definición de orientacións de xestión xerais para cada tipo de masa (modelos silvícolas), en asegurar a persistencia incidindo no equilibrio de clases de idade e en asegurar unha distribución adecuada no espazo dos tipos de cuberta forestal. Este marco xenérico de actuación concrétase en cada ordenación dando coherencia temporal á xestión, pero dun modo tan flexible como requira o xestor. A planificación a longo prazo constitúese a partir da suma das ordenacións sucesivas.

E engaden:

[E]n montes pequenos (e por tanto sen a cuarta premisa clásica da ordenación de montes de acordo con Mackay, a extensión suficiente, ou con esta premisa moi atenuada), este balance de clases de idade sería de moi difícil consecución, e por tanto debería obviarse.

Se o panorama da ordenación de montes en xeral non é moi alentador, cando deixamos atrás os montes públicos ou de xestión pública e analizamos o seu papel na xestión forestal privada e, en particular, a xestión de propietarios forestais particulares, comprobamos como permaneceu durante o último século á marxe dela, por complexa e por afastada da ortodoxia da ordenación de montes. 
Autores como Rojo et al. (1998) entendían que «[coa estrutura da propiedade particular en Galicia] resulta imposible a ordenación de montes, ao non cumprirse a condición de extensión suficiente, necesaria para a consecución do obxectivo dasocrático de rendemento sostido [de Mackay]». Tamén, a modo de ilustrativo exemplo, baste citar a Madrigal (1998), unha das autoridades académicas máis recoñecidas no campo da ordenación de montes, que, nun artigo denominado nin máis nin menos que «Problemática de la ordenación de masas artificiales en España», despacha o problema coa seguinte frase: «Deixando á parte a problemática da posible ordenación dos minifundios forestais, que requiriría non só solucións técnicas, senón de política forestal [...]».

Implicitamente, posturas como as dúas ilustradas acaban pretendendo afirmar, de maneira utópica, que non merece a pena adaptar métodos á realidade: é moito mellor afrontar a parte máis sinxela desta e esperar (infrutuosamente) a que a realidade converxa coa ortodoxia.

\subsubsection{Os instrumentos de ordenación forestal noutros paises}

As mesmas palabras e conceptos de «ordenación» e "métodos de ordenación», que están a ter unha longa supervivencia na práctica e a xerga dos forestais españois, hai moito tempo foron abandonados noutros países. Alí onde deixaron atrás estas polémicas sobre métodos e clasificacións fálase simplemente de forest management. A este respecto, é significativo que, no dicionario da Sociedad Española de Ciencias Forestales, o termo inglés management sexa o elixido como tradución tanto da palabra ordenación como da palabra xestión.

Cadro 2. Definicións de ordenación e xestión

Ordenación: Silv. e pascic. Proceso de análise, diagnóstico e planificación dun territorio que leva á programación de actuacións para conseguir a máxima rendibilidade sostida, económica e ecolóxica dun recurso, en conservación e mellora do medio en función das súas condicións naturais, dos outros usos e aproveitamentos existentes, da legalidade vixente e dos obxectivos pretendidos. Inglés: management

Xestión: Ord. for. e econom. Administración dun monte. Inglés: management

(Fonte: dicionario da Sociedad Española de Ciencias Forestales [2005])

Ademais, os conceptos imperantes, sobre todo no que se refire aos montes privados que presentan obxectivos principalmente económicos, buscan dotar o 
propietario ou xestor forestal de liberdade para establecer o seu propio «plan de negocio» e facilitar que o comunique aos responsables de velar polo interese xeral.

Esta idea abunda no concepto dado pola Society of American Foresters, que en 1950 definiu a ordenación de montes como «a aplicación de métodos comerciais e principios silvícolas ao manexo dun monte». Consecuentemente con esta, en 1966 a FAO definiuna como "toda a gama de actividades de dirección, ao nivel empresarial, que se executan para alcanzar os obxectivos fixados polo propietario».

Por exemplo, en Suecia a figura de referencia vén sendo, desde hai uns anos, o green forest management plan, no cal para cada propiedade se formulan uns obxectivos a longo prazo mediante a clasificación do terreo en catro clases-tipo: PG (produción con consideracións xenéricas de conservación), PF/K (produción con consideracións de conservación reforzadas), NS (xestión para a conservación) e NO (conservación íntegra, onde non se intervirá en absoluto). Existen uns límites de canta superficie mínima debe establecerse en cada unha das categorías excepto para parcelas inferiores a 20 hectáreas. Alén diso, é significativo facer notar que non hai ningún estándar oficial que dispoña que información teñen que conter estes plans ou que métodos se han de empregar para a súa elaboración. Con todo, normalmente a petición do propietario, o plan inclúe aspectos como inventarios detallados ou outras medicións, que ademais serven para axustar, pola súa exactitude final, a retribución que deben percibir os autores do plan.

Finlandia (Nuutinen 2006) apostou con forza pola elaboración de plans comarcais e rexionais, así como unha infraestrutura de datos espaciais e de inventario que poida ser usada a escala de propiedade. Os propietarios teñen a posibilidade de solicitar, a un custo de entre 7 e 10 /ha, a particularización da devandita información para as súas propiedades nun plan de xestión individual. Nun contexto moi parecido, no caso de Noruega (Eid 2006), a crítica por parte dos propietarios forestais sobre a utilidade dos plans e o seu custo fixo que boa parte dos «inventarios» se levasen a cabo sen traballo de campo tradicional.

As conclusións máis relevantes destes exemplos internacionais de planificación forestal en montes privados son as seguintes: 
a) Non se pode comparar a superficie forestal situada baixo este tipo de instrumentos coa «superficie forestal ordenada» en España, xa que finalidade, contido, custos e métodos difiren radicalmente.

b) Nestes países, en xeral a planificación en montes privados enténdese como unha ferramenta de axuda ao silvicultor na que se pon en xogo a información que producen ou posúen os organismos públicos forestais.

c) Os traballos de inventario que debe sufragar o propietario forestal dependen do seu mero interese en obter máis coñecementos e cuantificacións sobre o estado do seu monte.

d) Desde o punto de vista do interese público, búscase que os plans sirvan para que os propietarios forestais coñezan e apliquen as restricións legais sobre áreas de conservación e demais elementos.

\subsubsection{A ordenación forestal no marco xurídico}

A Lei 43/2003, de montes (LBM), coas modificacións aprobadas pola Lei 10/2006, a Lei 21/2015 e a Lei 9/2018, así como diversas sentenzas do Tribunal Constitucional, establece no seu artigo 33 o seguinte:

1. As administracións públicas impulsarán técnica e economicamente a ordenación de todos os montes.

2. Os montes declarados de utilidade pública e os montes protectores deberán contar cun proxecto de ordenación de montes, plan dasocrático ou outro instrumento de xestión equivalente.

3. A elaboración dos ditos instrumentos farase a instancia do titular do monte ou do órgano forestal da comunidade autónoma e os instrumentos deben ser aprobados, en todo caso, por este último.

4. O contido mínimo dos proxectos de ordenación de montes e plans dasocráticos determinarase nas directrices básicas comúns para a xestión forestal sostible e o aproveitamento de montes establecidas no artigo 32. A elaboración destes instrumentos deberá ser dirixida e supervisada por profesionais que conten con titulación forestal universitaria e deberá ter como referencia, de ser o caso, o PORF en cuxo ámbito se atope o monte. 
5. O órgano competente da comunidade autónoma regulará en que casos pode ser obrigatorio dispoñer dun instrumento de xestión para os montes privados non protectores e públicos non catalogados.

Ademais, na súa disposición transitoria segunda outorga un prazo de 25 anos para que os montes que estean obrigados a isto se doten dun instrumento de xestión forestal. Alén do anterior, aqueles que 15 anos despois da entrada en vigor da lei non tivesen instrumento de xestión aprobado non poderían acollerse, salvo excepcións, aos incentivos recolleitos nos artigos 63 e posteriores (estes prazos eleváronse de 15 e 10 anos, respectivamente, a 25 e 15).

No ámbito autonómico, a Lei 7/2012, de montes de Galicia (LMG), establece nos seus parágrafos 77.4, 77.5, 77.6 e 77.7 que aqueles montes públicos e veciñais, privados e agrupacións destes últimos que teñan superficies «en couto redondo» superiores a 25 hectáreas deberán dotarse dun plan de ordenación. No resto dos casos, é dicir, montes privados (sexa cal for a súa tipoloxía) de menos de 25 hectáreas en couto redondo, haberán de dotarse dun instrumento de xestión forestal ou terá que planificarse a súa xestión a través da súa adhesión expresa a referentes de boas prácticas e aos modelos silvícolas orientativos, segundo especies ou formacións forestais, previstos no artigo 76.3.

Tanto a LBM como a LMG recoñecen a enorme importancia de ordenar os terreos forestais, aínda que non dedican nada a xustificar esta importancia, coma se fose algo sobre o que non deberían albergarse dúbidas. Por tanto, sexa ou non razoado, e sen facer outras apreciacións sobre a idoneidade da dita medida, ha de considerarse a ordenación e a implantación de instrumentos de xestión forestal como un imperativo legal.

A modo de exemplo cabe citar que a LMG, no seu parágrafo 44.h, inclúe o "cumprimento do instrumento de ordenación ou xestión forestal» entre os deberes dos propietarios de montes privados. A pesar diso, recoñece entre os dereitos dos propietarios a «elaboración dos instrumentos de ordenación ou xestión forestal nas súas propiedades».

Para alén do dito, LBM e LMG vinculan o réxime de autorizacións de aproveitamentos forestais á existencia dun instrumento de xestión, e xorde unha evidente ameaza de que aqueles montes non ordenados queden fóra de calquera sistema de incentivos económicos que conten coa participación do Estado. 
A LMG, no seu apartado de definicións, en concreto na de instrumentos de ordenación ou xestión forestal, indica que «serven para facer unha planificación da xestión sustentable, co fin de que sexa socialmente beneficiosa, economicamente viable e medioambientalmente responsable». No seu artigo 77 establece:

1. A ordenación de montes ten como finalidade a conservación, mellora e protección dos recursos forestais, o seu rendemento sustentable e a máxima obtención global de utilidades. Estes fins deben contribuír ao desenvolvemento rural, á xeración de rendas, á fixación da poboación, á calidade paisaxística e ao mantemento da biodiversidade.

No seguinte parágrafo engade:

2. A ordenación de montes supón a organización no tempo e espazo, tecnicamente xustificada, dos recursos forestais, de todos os aproveitamentos do monte e das especificacións técnicas para a súa xestión sustentable.

Á parte da finalidade pola que o lexislador incluíu a obrigatoriedade de dotarse dun instrumento de ordenación ou xestión forestal, na práctica o devandito instrumento debería servir para estes fins:

a) Facilitar a obtención de autorizacións, permisos e comprobacións que a lexislación, en prol de salvagardar o interese xeral, impuxo sobre as actividades forestais privadas.

b) Dar, mediante o concurso da Administración, unha mínima seguridade xurídica ao propietario ou xestor forestal sobre a actividade a longo prazo que pretende levar a cabo nos seus montes ou parcelas.

c) Facilitar a comunicación a terceiras partes (entidades de certificación, usuarios etc.) sobre o tipo de xestión que desenvolver pola propiedade.

d) Avaliar, na extensión e coa precisión que a propiedade queira asumir, a xestión que ten que realizarse na parcela.

e) Definir as medidas básicas de prevención de incendios forestais que han de adoptarse.

En definitiva, a «ordenación» debe pasar a ser sempre un conxunto de compromisos bidireccionais, entre a propiedade e a sociedade (representada, na maior parte das ocasións, pola Administración competente), a respecto das liñas xerais de xestión que desenvolver nunha propiedade específica. 
É certo que, como moi a miúdo se expón, «a xestión sen planificación é simple improvisación». Malia todo, non é menos certo que, feito público ou non, o propietario forestal adoita ter un plan máis ou menos complexo da súa xestión, aínda que ás veces non pase dunha intención, unha expectativa ou incluso unha rutina. O que se dá con maior frecuencia é a planificación sen xestión, un mero exercicio tecnocrático afastado da realidade ou, no mellor dos casos, un documento obsoleto desde o minuto seguinte á súa redacción.

A ordenación en montes privados de carácter produtivo, a pesar do que parecen querer impor os textos lexislativos, non é un fin en si mesmo, senón un medio para unha mellor xestión e, sobre todo, para compartir información básica sobre «a empresa» do propietario. Non é un proxecto de investigación, nin un traballo de erudición: pola contra, debe ser un documento simple, ben estruturado, normalizado e manexable (e, até onde sexa posible, informatizado ou automatizado).

A SECF (2008) recoñeceu que «a planificación non serve de nada se non se aplica na xestión. Desde este punto de vista, podemos afirmar que "a mellor ordenación é a que se aplica”. Debemos, pois, facilitar a xestión forestal, cunha planificación realista, eficiente e que poida dar resposta ás necesidades da sociedade en cada momento». Por tanto, é preciso apostar por métodos e modelos de xestión ordenada, máis que por métodos de ordenación da xestión.

Normalmente, esta simplificación dos antigos conceptos e métodos ortodoxos xera ansiedade en colectivos técnicos e académicos. Mesmo con frecuencia se cualifica de falta de rigor, sumada a unha falta de control sobre a actividade forestal que pon en risco os valores que as administracións deben defender. Non obstante, se tomamos a suficiente perspectiva veremos que non é tal. A conservación e a protección dos montes foron abordándose ao longo do tempo mediante o despregamento dunha prolixa, e cada vez máis confusa, batería de figuras de protección, frecuentemente solapadas e que proceden de distintos ámbitos disciplinares.

A conservación e a protección dos montes veñen reguladas pola Lei, básica ao amparo do establecido no artigo 149.1.23 da Constitución española, de montes de 2003 (modificada en 2006 e 2015) e as correspondentes lexislacións autonómicas, que xeraron instrumentos como o Catálogo de montes de utilidade 
pública e o Plan forestal español de 2002, coas súas réplicas autonómicas; a eles, sen chegar á unidade de xestión, hai que engadir os Plans de ordenación de recursos forestais (PORF). Noutros ámbitos aparecen figuras como as de conservación da natureza (parque nacional, parque natural, Rede Natura 2000...), cada unha cos seus instrumentos de planificación (PORN, PRUG, plans directores...). Por outra banda, xorden planificacións específicas, como as de protección do patrimonio cultural, plans hidrolóxicos, plans de ordenación do litoral, directrices de ordenación do territorio e, amais diso, o conxunto de plans xerais de ordenación urbanística e municipal de cada un dos concellos.

Como se desprende da totalidade do anterior, e sen entrarmos aínda no nivel do monte, non parece que esteamos carentes de ferramentas legais de regulación e planificación do espazo forestal, senón máis ben ao contrario. Así, todo apunta a unha excesiva proliferación normativa, de difícil encaixe e arrevesada xerarquía.

A modo de exemplo desta situación, cabe citar o traballo de Ávalos (2017) sobre a xestión dun patrimonio rural familiar. Partindo dunha superficie total de 12,1742 ha, unha vez descontadas aquelas restrinxidas ao uso forestal, afectadas pola aplicación de distancias mínimas establecidas pola normativa e situadas en zonas de servidumes administrativas (augas, estradas...), resulta unha superficie efectiva de xestión de 4,0715 ha, é dicir, pouco máis dun terzo da superficie inicial (ilustracións 2 e 3).

Décadas de experiencia en ordenación de montes demostraron que, especialmente no que se refire a montes privados de mediano e pequeno tamaño, os instrumentos que configuraban as instrucións xerais para a ordenación de montes arborizados (IGOMA) son custosos e complexos, inclúen información prescindible e reiterativa, as súas prescricións adoitan ser abandonadas ao pouco tempo da súa redacción, a precisión alcanzada no inventario non xustifica os custos asumidos neles e até a data non supuxeron unha grande axuda á xestión nin á relación coa Administración forestal.

Tendo iso en conta, o desafío principal é entender, prioritariamente, a «ordenación forestal» como a organización no espazo e no tempo da silvicultura e, de maneira simultánea, como instrumento tanto para a declaración de intencións da propiedade como para a avaliación por parte da Administración responsable de velar polo interese xeral. 
Ilustración 2
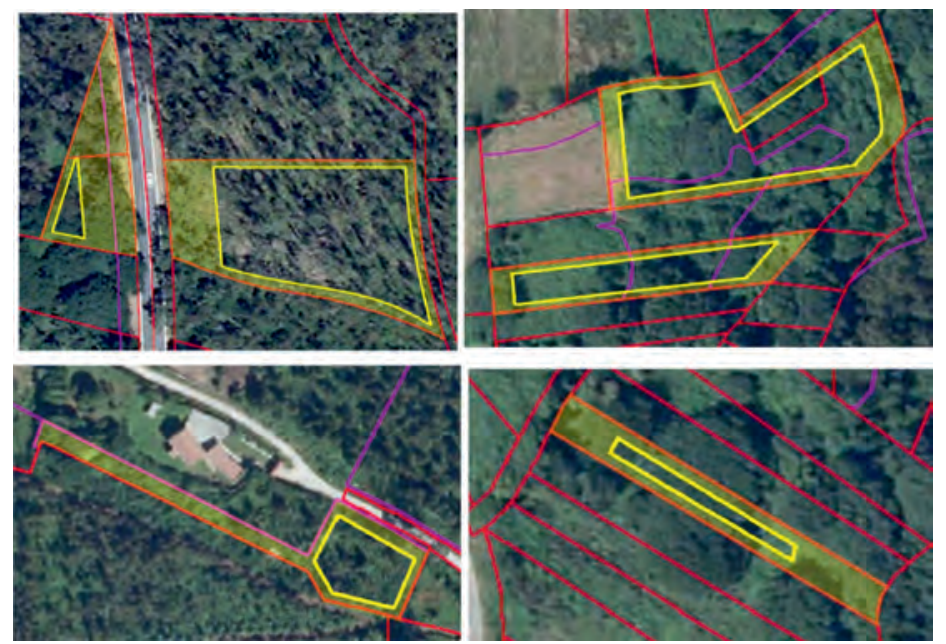

Ávalos (2017): Ejemplo de gestión de un patrimonio rural familiar según la Ley 7/2012 de Montes de Galicia Ilustración 3
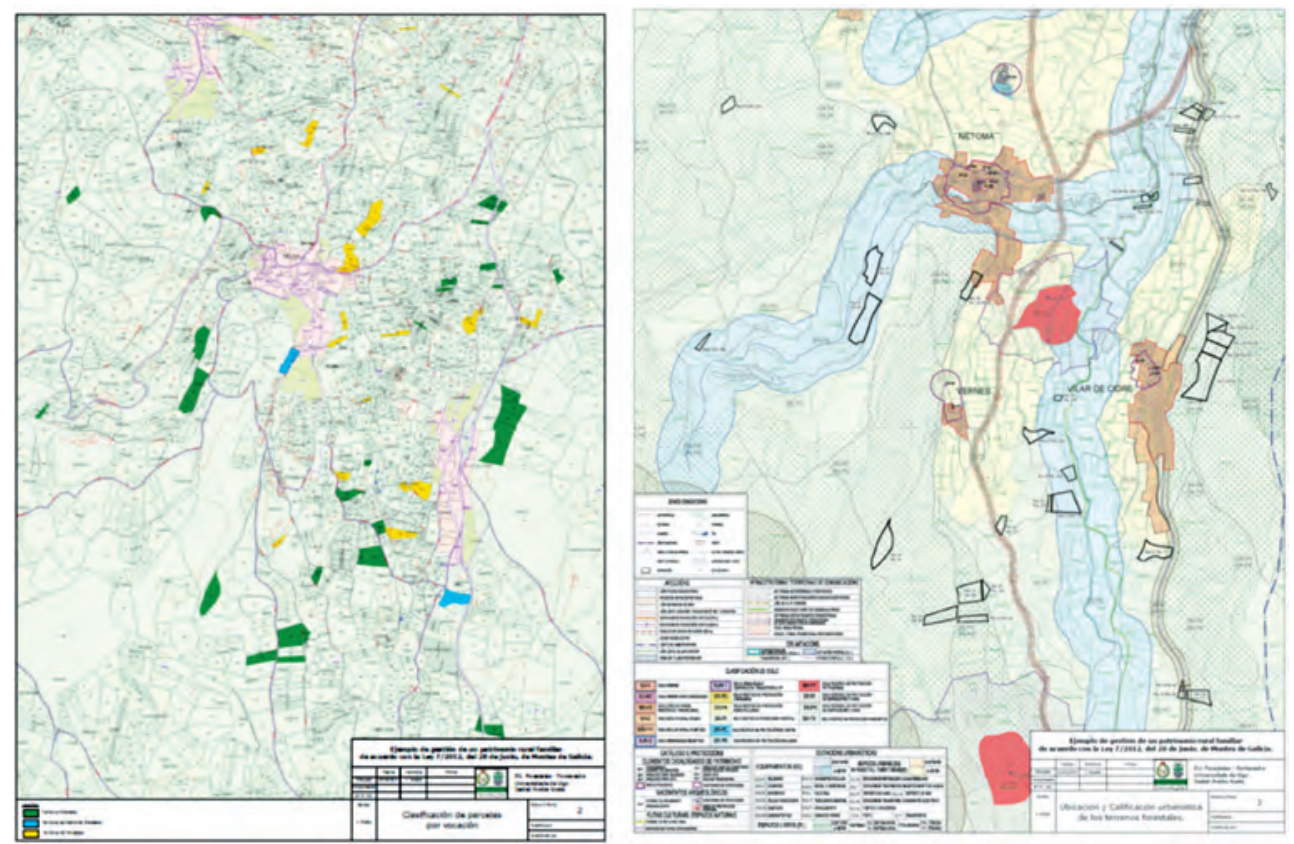

Ávalos (2017): Ejemplo de gestión de un patrimonio rural familiar según la Ley 7/2012 de Montes de Galicia 
Deste xeito, é en extremo interesante o camiño emprendido pola Lei 7/2012, do 28 de xuño, de montes de Galicia e, con posterioridade, o Decreto 52/2014, do 16 de abril, polo que se regulan as instrucións xerais de ordenación e de xestión de montes de Galicia. Este marco, aínda non totalmente posto en marcha e resumido na táboa 6 , tenta ser superador das eivas do marco normativo vixente desde os anos 70, para promover a planificación da xestión forestal sustentable do monte en Galicia, en especial nos montes particulares de pequeno tamaño.

É acertado que o Decreto trate de simplificar os requisitos administrativos mínimos do inventario, deixando no titular ou promotor do instrumento de xestión a potestade de levar a cabo traballos máis detallados, máis precisos, ou de utilizar as tecnoloxías e métodos que considere de utilidade para a súa xestión.

Resulta adecuado o emprego, como base territorial, da referencia catastral, en cumprimento da obrigación legal emanada do artigo 38 do Real decreto lexislativo $1 / 2004$, do 5 de marzo, polo que se aproba o texto refundido da Lei do catastro inmobiliario. No entanto, é oportuno advertir que esta obrigará a promover unha activa cooperación da Xerencia do catastro co fin de afrontar as numerosas solicitudes de corrección ás que haberá que facer fronte e mesmo para poder procesar solicitudes de instrumentos de xestión con referencias catastrais antigas ou en lugares onde o catastro non foi revisado recentemente.

De igual maneira, para o éxito do establecido no Decreto, será imprescindible a decidida colaboración dos distintos órganos da Administración que xestionan información que pasa a ser imprescindible para a redacción dos instrumentos de xestión. A publicación de documentación cartográfica, nun modo utilizable polos solicitantes, sobre aspectos como clasificación urbanística, patrimonio cultural e arqueolóxico, áreas afectadas por incendios forestais, datos cartográficos dos plans de distrito etc. condicionará en gran medida o éxito final da reforma proposta. Un grande avance é o que supón a recente publicación da base cartográfica do Plan básico autonómico e dos visores asociados aos trámites de autorización de aproveitamentos forestais (táboas 6 e 7). 
Táboa 6. Tipoloxía dos instrumentos de ordenación ou xestión forestal segundo o Decreto 52/2014

\begin{tabular}{|c|c|}
\hline Instrumento & Requisitos/Características \\
\hline $\begin{array}{l}\text { ADHESIÓN } \\
\text { A MODELOS } \\
\text { SILVÍCOLAS } \\
\text { E CÓDIGOS } \\
\text { DE BOAS } \\
\text { PRÁCTICAS } \\
\text { DE XESTIÓN } \\
\text { (MS) }\end{array}$ & $\begin{array}{l}\text { - Individual } \\
\text { - } \leq 15 \text { ha de propiedade en couto redondo } \\
\text { - Adhesión a modelos silvícolas (MS): un ou varios MS (só da Orde ou PORF) por } \\
\text { referencia catastral } \\
\text { - Compromiso de boas prácticas de xestión (BPX) definidos pola Orde ou polo PORF } \\
\text { - Por comunicación á Administración forestal do propietario } \\
\text { - Non redacción técnico-forestal nin codificación telemática } \\
\text { - Monte recoñecido baixo xestión forestal, só para os efectos das axudas FEADER } \\
\text { - Necesidade de autorización para cada actuación, de ser o caso } \\
\text { - Non-exención da distancia entre parcelas ( } 2 \text { m); Lei } 7 / 2012\end{array}$ \\
\hline $\begin{array}{l}\text { DOCUMENTOS } \\
\text { SIMPLES/ } \\
\text { CONXUNTOS } \\
\text { DE XESTIÓN } \\
\text { (DSX/DCX) }\end{array}$ & $\begin{array}{l}\text { - Un ou varios propietarios (comparten xestión) } \\
\text { - } \leq 25 \text { ha cada propiedade en couto redondo } \\
\text { - Individual/conxunto de propiedades } \\
\text { - Para cada referencia catastral: afectación ao réxime de protección, inventario forestal } \\
\text { (descritivo, estimado - non parcelas-), adhesión a MS e código de BPX (da Orde ou } \\
\text { PORF ou especificamente creado) } \\
\text { - Non é instrumento de ordenación (métodos), só de xestión (MS-BPX) } \\
\text { - Redacción por un técnico e codificación previa telemática } \\
\text { - Aprobación pola Administración forestal } \\
\text { - Non necesarias autorizacións administrativas (Rede Natura...) despois da aprobación } \\
\text { - Potestativamente, exención da distancia entre parcelas contiguas do mesmo instrumento }\end{array}$ \\
\hline $\begin{array}{l}\text { PROXECTO DE } \\
\text { ORDENACIÓN } \\
(P O)\end{array}$ & $\begin{array}{l}\text { - Individual/conxunto (mesmo xestor ou propietario) } \\
\text { - Montes de xestión pública e montes privados de > } 25 \text { ha en couto redondo } \\
\text { - Estudo da afectación de réximes de protección } \\
\text { - Inventario forestal estimado (parcelas só en superficies que cortar antes do final do plan } \\
\text { especial) } \\
\text { - Aplicación de métodos de ordenación: monte dividido en cuarteis de ordenación, } \\
\text { método de ordenación, creación de unidades (tramos, tranzóns...) } \\
\text { - Redacción por un técnico forestal e codificación previa telemática } \\
\text { - Aprobación pola Administración forestal } \\
\text { - Non necesarias autorizacións administrativas (Rede Natura...) despois da aprobación }\end{array}$ \\
\hline
\end{tabular}

Táboa 7. Número de instrumentos de xestión no rexistro de montes ordenados da Consellería do Medio Rural

\begin{tabular}{|l|r|r|r|r|r|r|r|}
\hline & \multicolumn{3}{|c|}{$\mathbf{0} \mathbf{3 0 / 1 1 / 2 0 1 8}$} & \multicolumn{2}{c|}{ Antes de 16/4/2014 } & \multicolumn{2}{|c|}{ Despois de 16/4/2014 } \\
\hline Tipo de instrumento & $\mathbf{N}^{\mathbf{0}}$ & Superficie (ha) & Sup. media (ha) & $\mathbf{N}^{\mathbf{0}}$ & Superficie (ha) & $\mathbf{N}^{\mathbf{0}}$ & Superficie (ha) \\
\hline $\begin{array}{l}\text { Documento simple } \\
\text { de xestión }\end{array}$ & 5 & 78,68 & 15,74 & - & - & 5 & 78,68 \\
\hline $\begin{array}{l}\text { Plan técnico de } \\
\text { xestión }\end{array}$ & 175 & 28962,25 & 165,50 & 171 & 28910,43 & 4 & 51,82 \\
\hline $\begin{array}{l}\text { Proxecto de } \\
\text { ordenación }\end{array}$ & 570 & 197625,54 & 346,71 & 393 & 152190,08 & 177 & 45435,46 \\
\hline Outros análogos & 3 & 74,58 & 24,86 & 3 & 74,58 & - & - \\
\hline Total xeral & 753 & 226741,05 & 301,12 & 567 & 181175,09 & 186 & 45565,96 \\
\hline
\end{tabular}




\subsubsection{A ordenación a escala de paisaxe}

Se aceptamos, pois, a «ordenación» como a organización da silvicultura no espazo e no tempo, esta debería incluír a organización da silvicultura preventiva a escala de unidade de xestión.

Cabe lembrar que a maior parte das unidades de xestión forestal posúen un escaso tamaño (o $80 \%$ das parcelas forestais son inferiores a media hectárea [Picos 2015]). Ademais, algunhas das principais medidas preventivas de incendios forestais descritas en apartados anteriores débense deseñar e executar a unha escala de «paisaxe». Ambas as dúas circunstancias obrigarían, pois, a analizar unha hipotética escala de "ordenación ampliada», entendida como artellamento da silvicultura preventiva no espazo e no tempo a escalas superiores ás da unidade de xestión e inferiores á comarcal.

A lexislación autonómica (artigo 74 da LMG) prevé a aprobación de plans de ordenación dos recursos forestais (PORF) como instrumentos de planificación forestal, que afectarán preferentemente a cada distrito forestal, en canto territorios de condicións xeográficas, socioeconómicas, ecolóxicas, culturais ou paisaxísticas homoxéneas. O contido destes plans (estipulado no artigo 76) deberá coordinarse cos correspondentes plans de prevención e defensa contra os incendios forestais de distrito establecidos no artigo 15 da Lei 3/2007, do 9 de abril, de prevención e defensa contra os incendios forestais de Galicia.

O plan de prevención e defensa contra os incendios forestais de distrito (PPDCIFD) desenvolve as orientacións previstas na planificación establecida no Plan de prevención e defensa contra os incendios forestais de Galicia (PLADIGA), facilitando un marco de referencia para levar a cabo a prevención, defensa e extinción de incendios forestais a escala de distrito forestal, adecuado ás características, problemática e necesidades na materia de cada territorio forestal, minimizando o número de incendios e as superficies afectadas por eles.

A Lei 3/2007 establece que a consellaría competente en materia forestal poderá crear e aplicar programas especiais de intervención no ámbito dos PPDCIFD para áreas forestais contiguas a infraestruturas de elevado valor estratéxico e para áreas forestais estratéxicas de elevado valor, de acordo co establecido nos PORF. Igualmente, nos ditos plans poderán establecerse zonas de actuación preferente para os efectos de prevención de incendios, no marco de cuxa xestión será 
posible concertar convenios de colaboración coa propiedade ou axudas específicas.

No tocante a cada unha das zonas de alto risco de incendio (ZAR) definidas pola Orde do 18 de abril de 2007, a Lei prevé que sexa elaborado un plan específico de defensa, que se integrará no PPDCIFD e que, entre outros aspectos, terá en conta as medidas e os traballos preventivos aplicables a elas. Estes traballos preventivos incluirán devasas, vías de acceso e puntos de auga que «deben realizar as persoas titulares dos montes da zona» [sic], así como os prazos e as modalidades de execución, «sen prexuízo da colaboración coas administracións públicas» $[$ sic].

Por último, os PPDCIFD atenderán exhaustivamente ao disposto na Lei 4/2015, do 17 de xuño, de mellora da estrutura territorial agraria de Galicia, en canto á declaración de perímetros abandonados de leiras de vocación agraria por parte do órgano superior competente en materia de agricultura cando poidan supor risco de incendios forestais, ben pola non-aplicación ou ineficacia das medidas contidas nos correspondentes plans de xestión ou de ordenación forestal, ben pola inexistente xestión da biomasa ou polas reiteradas neglixencias no uso do lume en prácticas de xestión agroforestal ou doutros conflitos que deviñeron na reiteración de incendios nesas zonas, co consecuente perigo para as áreas habitadas próximas a elas.

Todas estas disposicións apuntan ao decisivo papel que PPDCIFD e PORF deberían ter na execución de medidas preventivas en escalas superiores á da unidade de xestión forestal.

A realidade, hoxe en día, non indica o mesmo. Desde a aprobación da LMG, non se fixo o propio con ningún PORF e, once anos despois da aprobación da Lei 3/3007, os únicos PPDCIFD foron os sancionados mediante a Orde do 13 de marzo de 2009 e non se adoptou ningún plan específico de defensa para as ZAR. Ademais, desde 2009, estes PPDCIFD nunca foron avaliados na súa execución nin revisados, malia que na súa definición figura que deben desenvolver as orientacións previstas no PLADIGA, que é aprobado anualmente. 


\section{QUEN E COMO?}

A propiedade forestal de Galicia é case na súa totalidade -98\%- de natureza privada. Aproximadamente dous terzos corresponden a propiedade privada individual e un terzo a propiedade privada colectiva (montes veciñais en man común).

Cando se producen episodios graves de incendios e, en particular, aqueles que afectan zonas próximas ás cidades, a reacción social e política tende a volver a súa mirada cara ao monte, buscando explicacións fáciles e rápidas e, en non poucos casos, reprochando ás áreas forestais que producisen esa situación de emerxencia.

No medio desta reacción, esquécese que os silvicultores e comunidades de montes son grandes afectados polos lumes e como tales merecen ser tratados. Non é frecuente explicitar publicamente o apoio a eles e en non poucas ocasións se deixa flotar unha néboa de «culpabilidade». O xuízo sobre as decisións que tomaron ou non os xestores forestais non adoita incluír unha discusión pausada sobre as alternativas reais, nun marco de mínima rendibilidade, que permitirían manter os combustibles forestais en condicións de menor dispoñibilidade e incrementar a diversidade de usos en zonas forestais.

Por outra parte, a propiedade vén sendo obxecto de tutela conceptualmente considerada como mera titularidade, con independencia do uso ou non-uso dela que fixese o propietario. Non se ten, en xeral, en conta a conducta dese uso, que, en case calquera senso, se considera lícito. A complexidade do marco legal e as novas esixencias da sociedade están dando paso a un concepto de explotación útil -individual e socialmente- dos bens. É dicir, a propiedade é un modo de acumular e conservar riqueza, pero tamén un medio para producila e para evitar danos sobre outras propiedades, bens ou servizos de interese público.

Nun territorio maioritariamente privado, onde a xestión directa, ao contrario que noutras áreas xeográficas, non corresponde aos poderes públicos, a misión da política forestal é a de servir de marco e, ao mesmo tempo, de panca para posibilitar a mellora da xestión de miles de axentes, compatibilizándoa coa defensa do interese xeral. 
Por tal motivo, débese afrontar a loita para superar a elevada fragmentación da propiedade, reverter o abandono das terras, fomentar a xestión agrupada e mellorar as condicións de produción, de forma que, complementariamente, aumente a competitividade da silvicultura e con ela a dunha boa parte do conxunto da cadea de valor.

\subsection{A necesidade de alternativas rendibles}

No caso de Galicia, a propiedade particular representa o $80 \%$ da superficie arborizada e achega o $90 \%$ das cortas anuais (XERA 2018). A superficie media é dunhas 0,25 ha (Picos 2015) e uns terreos tan reducidos dificultan a mecanización da silvicultura e os aproveitamentos forestais, encarecendo o seu custo até o extremo de poñeren en perigo a súa rendibilidade futura.

Os cambios acontecidos no mundo rural durante os últimos vinte anos, nomeadamente o abandono das explotacións agrarias, a redución da poboación activa agraria e o envellecemento da poboación residente no campo, xeraron unha transformación dese medio, incluída a conversión de terreos agrícolas en forestais, ben por acción, ben, en moitos casos, meramente por omisión. A emigración da poboación, o declive e desaparición da maioría das explotacións, o escaso interese agrario e a xubilación ou morte dos propietarios provocaron un cambio social de enorme alcance no agro galego, onde hoxe en día numerosas comarcas están a quedar practicamente despoboadas ou cun grao de envellecemento alarmante.

Xurdiu unha xeración de novos propietarios forestais, de natureza máis absentista, pola súa residencia afastada das súas propiedades, polo seu descoñecemento delas e pola súa falta de experiencia como produtores no medio rural.

Unha boa parte dos investimentos dos propietarios particulares de montes en Galicia, sen ser actividade económica principal, desempeña un papel de aforro non financeiro básico nas economías familiares de moitas áreas de Galicia. Segundo Confemadera (2014), o $9 \%$ das familias galegas obtiveron algunha renda procedente da venda de madeira.

O balance económico e os riscos dunha explotación forestal (que comece de cero), incluso sen contar o custo de adquisición do solo e con quendas 
«relativamente curtas», son, en termos financeiros en sentido estrito, pouco incentivadores (ilustracións 4 e 5). No obstante, as actividades forestais dos silvicultores privados, máis que a un concepto de «investimento», obedecen a un concepto de «aforro", mediante o cal se acumulan recursos a longo prazo mediante o uso dunha terra que herdaron, na maior parte dos casos. Actualmente o valor en recursos madeireiros acumulado no monte galego produtivo supón unha cantidade equivalente ao $7 \%$ ou $8 \%$ dos depósitos bancarios do país (Picos 2015). Este aforro amosou a súa importancia en momentos en que as familias tiveron que enfrontarse a situacións económicas difíciles, como as derivadas do desemprego.

Como xa foi analizado anteriormente neste documento, un dos factores máis prexudiciais que nas ultimas décadas sufriu este modelo foi a distorsión causada pola expectativa de especulación coa potencial urbanización do solo rústico (en especial nas comarcas máis poboadas). Unha axeitada ordenación do territorio e, sobre todo, o control sobre os procesos de cambio de uso son imprescindibles para a axeitada posta en produción nos longos prazos que require a xestión forestal.

$\mathrm{Na}$ liña do defendido por López-Iglesias (2018), todo o que queiramos que produzan os montes ten que ser pagado por alguén e debe responder a unha demanda real de bens ou servizos ecosistémicos. Non serven os usos impostos pola sociedade aos propietarios, sen compensación, como tampouco se pode basear o futuro dos territorios en alternativas meramente voluntaristas incapaces de manter a ceifa no medio prazo. Igual que se fan esforzos para, despois dos incendios, non perder o chan porque ten que ser sustento da masa forestal futura, a sociedade non pode permitir que se perdan xestores do territorio, «erosionados» despois de veren arder os seus montes.

$\mathrm{O}$ incremento da superficie forestal infraxestionada ou mesmo abandonada, ademais das obvias consecuencias desde o punto de vista produtivo, incrementa o risco de maiores e máis graves incendios, sobre todo nas áreas de interface urbano-forestal (ilustracións 4 e 5). 
Ilustración 4. Taxa interna de retorno (TIR) e necesidades financeiras para distintos modelos silvícolas dependentes de especie principal, quenda, produtividade e grao de mecanización

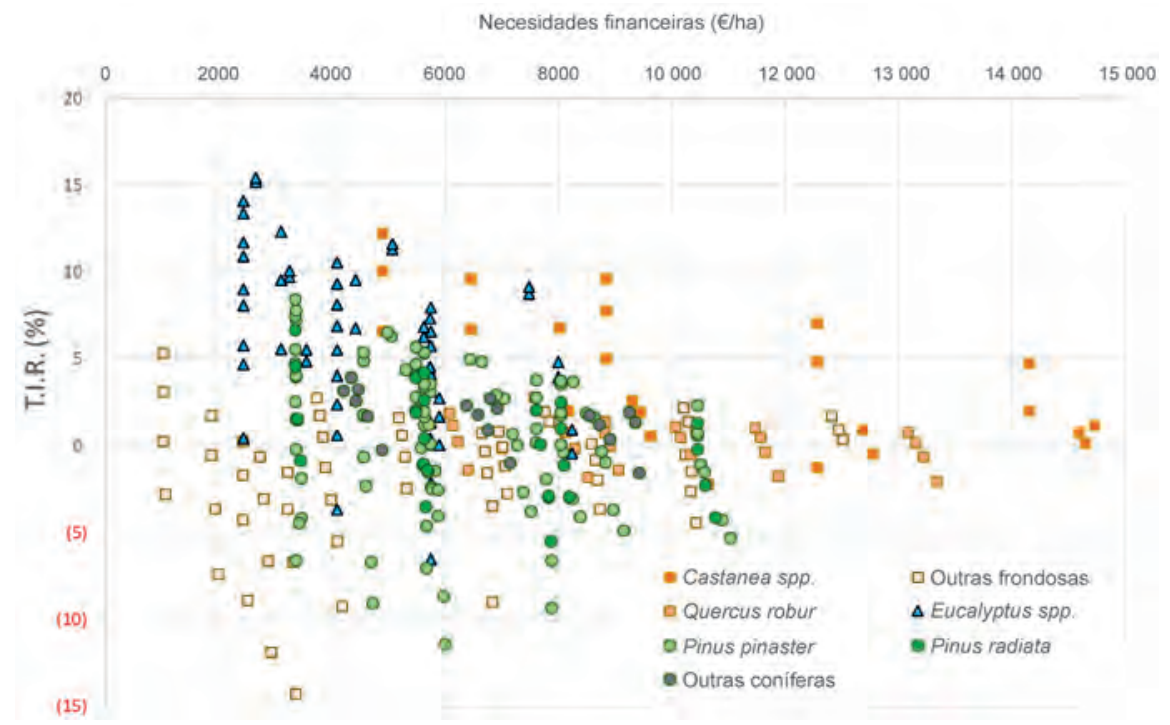

Fonte: Elaboración propia a partir dun informe da Asociación Forestal de Galicia (2017)

Ilustración 5. Necesidades financeiras e resultados para distintos modelos silvícolas dependentes de especie principal, quenda, produtividade e grao de mecanización

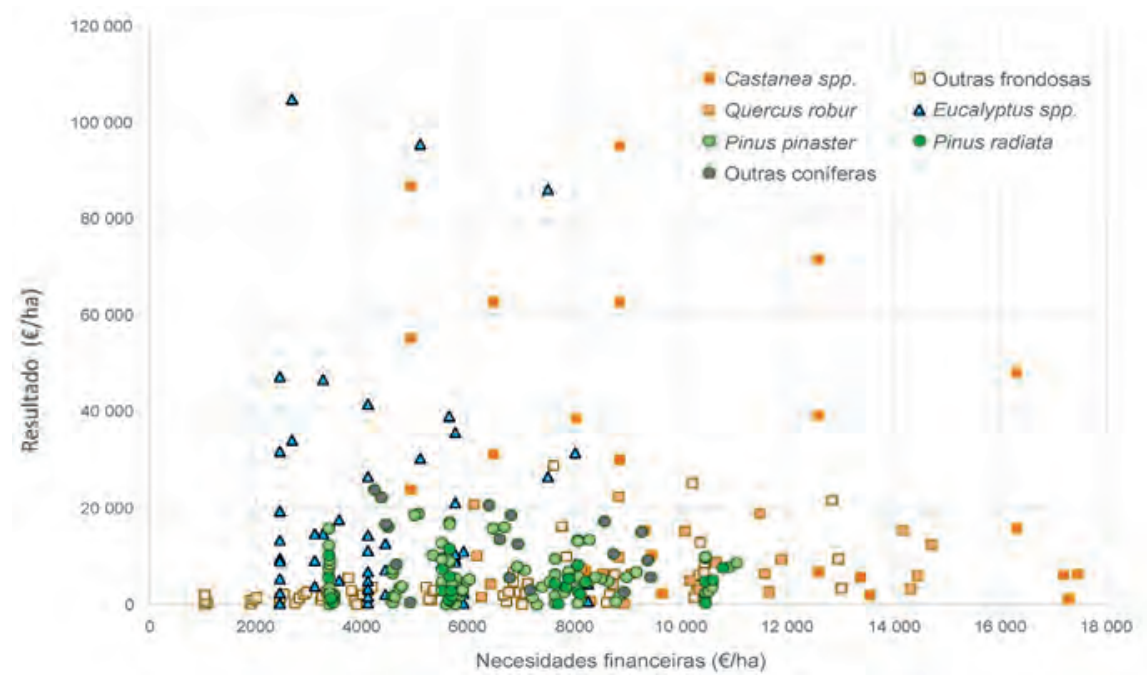

Fonte: Elaboración propia a partir dun informe da Asociación Forestal de Galicia (2017) 


\section{2. $\mathrm{O}$ abandono en áreas forestais}

Tendo en conta a modesta rendibilidade de moitas das alternativas forestais e a non-profesionalidade da maior parte dos silvicultores, non é estraño que os procesos de incremento da presión normativa ou impositiva se traduzan, ao contrario do que pretenden, en incrementos da superficie infraxestionada ou abandonada.

O abandono de terras e a consecuente diminución da superficie forestal obxecto de xestión activa constitúen unha preocupación importante nun gran número de rexións e países da Unión Europea. A definición dos conceptos de «abandono de terras» ou de «terra abandonada» non é unánime. Existen diversas aproximacións, entre as que destacan aquelas que entenden o abandono como un estado da terra (é dicir, analizado cun enfoque estático no tempo) e aqueloutras que o entenden como un proceso nunha escala temporal (analizado cun enfoque dinámico). De igual modo, é posible distinguir entre abandono dunha actividade e o propio abandono da terra (Corbelle e Crecente 2008).

En moitos casos, é difícil outorgar a cualificación obxectiva de «abandonadas» ás superficies forestais. Isto é debido a que usualmente veñen definidas por exclusión doutros usos ou actividades -como a agropecuaria ou a acción construtiva- ou mesmo pola evolución da vexetación tras o abandono das ditas superficies. Porén, o abandono en áreas forestais non é fácil de identificar sobre o terreo, unha vez que o crecemento da vexetación espontánea está condicionado pola actividade realizada e os longos prazos que poden mediar entre intervencións ou aproveitamentos silvícolas.

$\mathrm{Na}$ ilustración 6 móstrase unha aproximación alegórica ao proceso de abandono dos terreos forestais. Na devandita figura, enténdese o abandono como un proceso continuo no que poden distinguirse distintos estados, establecendo unha analoxía cun circuíto hidráulico composto por varios depósitos onde a auga flúe por gravidade. Deste xeito, pártese dun escenario óptimo (máxima altura e enerxía potencial) no cal a parcela está xestionada por un silvicultor activo e chégase a un estado, a menor cota e con menor enerxía potencial, no que se considera o abandono extremo (abandono irreversible).

No proceso de abandono, gradualmente vaise pasando por diversos estados intermedios, algúns dos cales poden englobarse dentro da fase de «semiabandono». 
Esta caracterízase porque a parcela segue aínda xestionada, recibindo algunha atención periódica, malia que progresivamente menos, e segue sendo, en todo caso, obxecto de aproveitamento. Ao mesmo tempo, comeza a haber unha certa «desidia» desde o punto de vista administrativo (por exemplo, o catastro xa non está actualizado, incúmprense ou descoñécense obrigacións normativas etc.). Este é un caso frecuente cando hai unha transmisión por herdanza e os novos propietarios xa non viven na contorna da propiedade ou a súa fonte principal de ingresos xa non está relacionada coa propiedade rural. O absentismo podería ser un caso particular desta categoría.

Cando a actividade na parcela cesa -e isto ocorre con frecuencia tras un aproveitamento ou un incendio- pero é aínda potencialmente «activable» polo propietario (este coñece a súa localización, se houbese unha oferta interesante podería vendela etc.), dicimos que a parcela se atopa no estado de «abandono reversible».

Se a situación segue deteriorándose, ou incluso se nese momento houbese un cambio de xeración, podería darse o caso de que a parcela xa non fose localizable polo propietario, ou até que a súa mera existencia fose descoñecida por el. Neste suposto diriamos que estamos nun estado de «abandono irreversible»: o estado ou destino da parcela non pode ser mudado polo mesmo dono dela. Propietario e propiedade aparecen totalmente desvinculados.

Como no caso dos depósitos sucesivos de auga, regresar a un estado anterior precisa dunha achega de enerxía ao sistema -un bombeo-. A enerxía necesaria para volver desde os estados inferiores ao estado inicial de «silvicultor activo" é progresivamente maior canto máis «abaixo» no circuíto se atope a auga. No caso do abandono, esta enerxía virá identificada co esforzo, económico, social ou normativo, requirido para activar o terreo. Por iso na liña punteada da figura se exemplifican medidas que van desde os incentivos, nos estados iniciais, até a intervención sobre a propiedade (expropiación, tutela administrativa...) nos finais.

Cando falamos de silvicultura preventiva a escala de paisaxe, debería empregarse a intervención pública sobre as áreas de abandono irreversible para desenvolver estratexias preventivas. Isto permitiría acadar obxectivos no establecemento de puntos estratéxicos de xestión ou na diversificación de combustibles, ou incluso favorecer permutas con propietarios sometidos a estas restricións noutras 
zonas. Tal política de presión sobre o abandono e incentivo sobre a xestión activa compatible representa unha oportunidade para fuxir do dilema de aplicar restricións que só afectarán a quen xestiona e non ao abandonado.

Obviamente, antes de aplicar medidas encamiñadas a reverter o circuíto, o primeiro obxectivo tería que ser frear o fluxo descendente, pechando as válvulas que separan cada un dos recipientes (en vermello na figura). Do mesmo xeito, para deter o proceso de abandono no territorio, antes (ou ademais) da toma de medidas ambiciosas para a reversión debería evitarse que o proceso seguise producíndose.

Ilustración 6. Representación alegórica do proceso de abandono dos terreos forestais

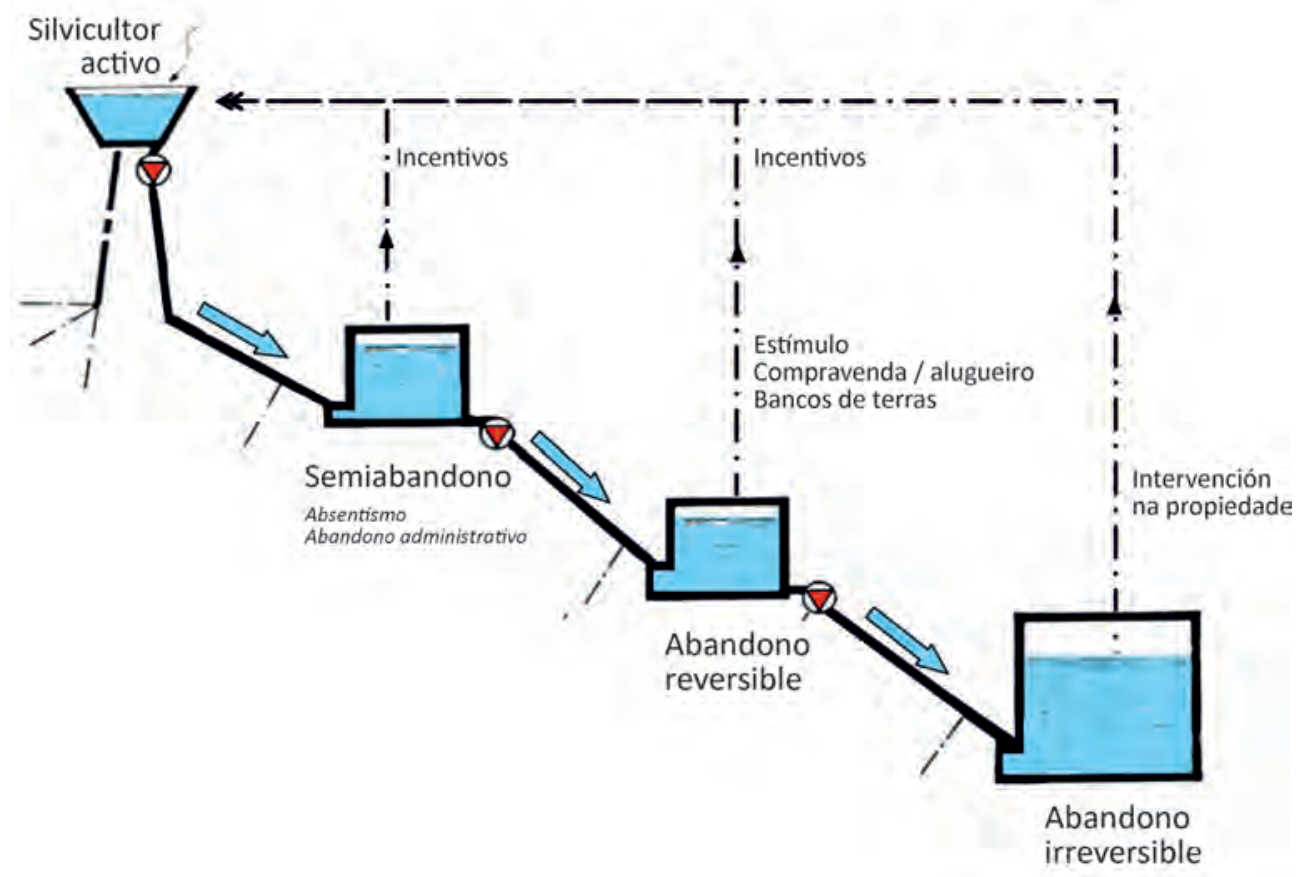

\subsection{A necesidade de segmentación das medidas}

Non é factible establecer de xeito nidio unha liña que separe a xestión forestal "correcta» da que non o é. A multiplicidade de posibles itinerarios silvícolas e os distintos valores que chegan a alcanzar as variables que poderían representar esa 
xestión obrigan a considerar a «bondade» da xestión forestal como un continuo, no cal normalmente é fácil distinguir os extremos, pero a gradación intermedia é, en moitos aspectos, sutil.

Supoñamos a existencia dunha función $\Phi$ que puidese representar de xeito sintético a «bondade» da xestión forestal (xestión forestal sostible, economicamente viable, socialmente axeitada e ambientalmente responsable) e que, ao mesmo tempo, estivese correlacionada cunha boa aplicación das medidas de silvicultura preventiva que foron indicadas en anteriores apartados. O que sería de agardar é que a distribución de frecuencias dos xestores forestais en función do valor de $\Phi$ puidese vir representada por unha curva unimodal convexa con certa asimetría (ilustración 7). Entón, un obxectivo da política forestal debería ser que a curva de $\Phi$, ou, polo menos, a súa maior área posible, se fose desprazando cara a maiores valores na parte dereita do gráfico (liña punteada da ilustración 7).

Ilustración 7. Aproximación gráfica ao proceso de segmentación e mellora da xestión forestal privada

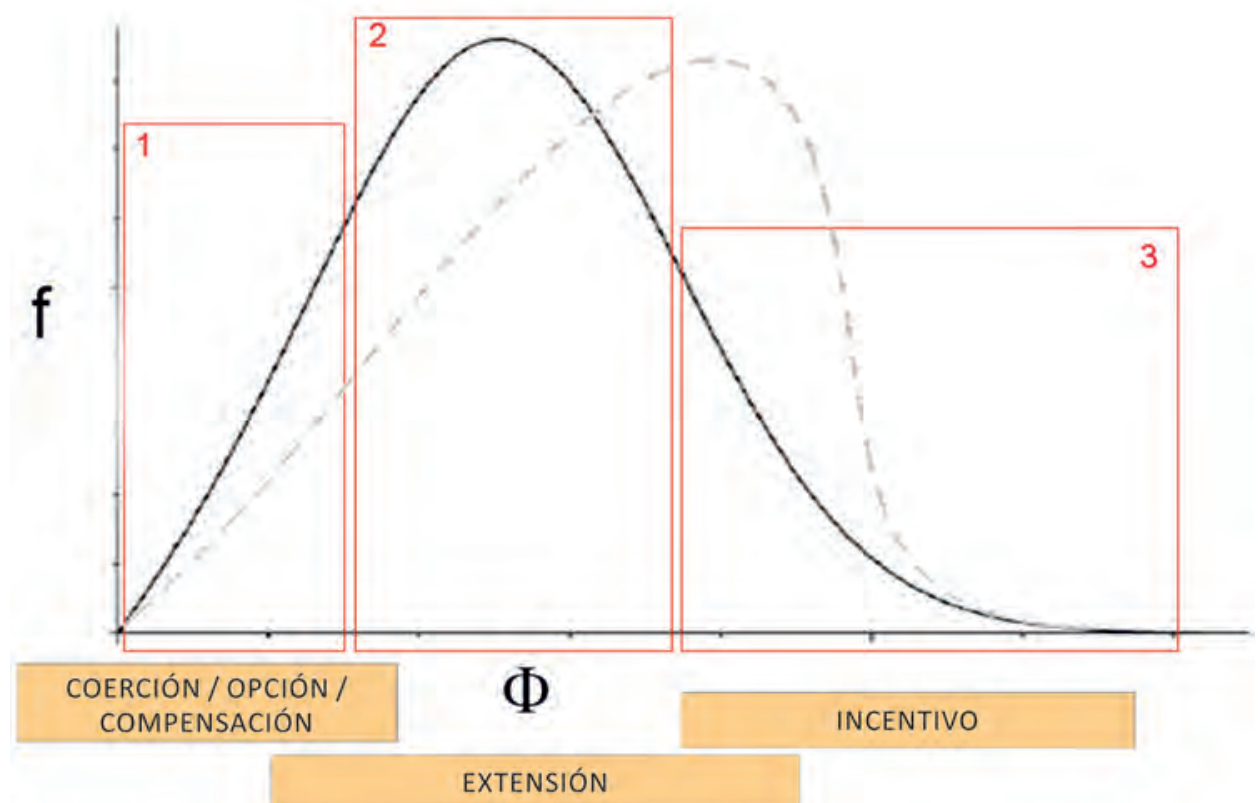

INVESTIGACIÓN E DESENVOLVEMENTO DE MELLORA E ALTERNATIVAS 
Dentro desta distribución poderíanse segmentar rexións con distinta problemática e, polo tanto, nas que tamén deberían aplicarse estratexias distintas.

A área correspondente á cola inicial (1), con valores máis baixos de $\Phi$, comprendería os xestores de prácticas máis afastadas do óptimo. Para estes casos, as principais ferramentas serían tanto aquelas de tipo coercitivo, nos casos en que non se estivese a cumprir a normativa, como a xeración de alternativas e compensacións para aqueloutros casos en que exista unha disfunción entre a expectativa de xestión ou produción por parte do silvicultor e a función preferente para o interese xeral. Este suposto é especialmente frecuente en espazos naturais protexidos e mesmo en áreas definidas para a xestión preventiva, puntos estratéxicos de xestión etc.

A zona central do gráfico (2) correspondería ao numeroso conxunto de xestores que teñen prácticas estándar para o territorio. Neste caso deberíanse aplicar ferramentas como a extensión, que permitiría que os silvicultores mellorasen a súa formación, as técnicas empregadas e o uso doutras alternativas que levasen a mellorar o valor da $\Phi$ da súa xestión.

A zona da cola superior (3) correspondería aos xestores que xa acadan valores elevados de $\Phi$, lindeiros o incluso superiores ao considerado como obxectivo. Estes xestores deberían ser recompensados con incentivos premium que tamén terían que servir de motivación para ser acadados por aqueles situados en partes máis baixas do gráfico.

Un proceso como este de segmentación dos xestores e das medidas que aplicar a cada unha das «tipoloxías» semella ser máis acaída que as aproximacións tradicionais. Normalmente aplícanse obrigas xenéricas, que non consideran diferencias entre territorios ou, o que é máis grave, entre tipo de xestión, que ao final acaban sendo incapaces de mudar a situación nas parcelas «infraxestionadas» ou abandonadas e que son aplicadas con máis dureza naqueles casos en que existe un xestor aínda activo. Deste xeito, os silvicultores rexeitan a imposición de restricións aos seus investimentos e, de maneira simultánea, increméntase o risco de abandono da xestión en casos actualmente activos. $\mathrm{O}$ reto preséntase en regular as parcelas deixadas en abandono, mobilizar aqueles territorios onde sexa prioritario facelo e intervir neles, e entender esas medidas, no canto de prexudiciais, como axudadoras e motivadoras do conxunto dos mellores xestores no territorio. 
Nun espazo forestal como o galego, tan extenso e complexo, as estratexias de mellora e ordenación dese espazo deben mudar a súa perspectiva. O experimentado fracaso da construción de arriba abaixo ten que deixar paso a unha construción moito máis precisa de abaixo arriba, facendo esforzos para ir acadando «o posible» co obxecto de ir «chegando», mediante a mellora continua, ao «bo».

Ninguén tentaría resolver un quebracabezas, aínda que poida ter unha guía de como quere que quede ao final, sen tomar atención das pezas e de como ir pouco a pouco encaixando e situando as que teña dispoñibles, reducindo os espazos de incerteza. E, alén diso, neste caso nin sequera estamos seguros de contarmos con todas as pezas necesarias, polo que teremos ademais que buscar como substituílas por outras que cumpran a súa función no conxunto.

Ao mesmo tempo, non hai que esquecer que unha parte da responsabilidade de evitar a reiteración de incendios catastróficos reside en decisións que cada compoñente da sociedade toma todos os días e que inflúen no territorio: onde e como se vive; que se consome; onde foi producido iso que se consome; se se está ou non disposto a pagar polo lecer que se desenvolve en áreas forestais, ou polo osíxeno ou a auga que producen; que se esixe aos representantes políticos; se se participa na comunidade de montes onde se reside; se se están buscando alternativas para pór en produción as parcelas forestais que se herdaron. Hai tarefa para todos antes dos incendios.

\section{CONCLUSIÓNS}

O agravamento percibido do patrón de incendios forestais ten a súa raíz na xestión da paisaxe, na escalada da continuidade e carga de combustible propiciada polo abandono das actividades rurais, intensificado polo cambio climático.

O estudo dos grandes incendios do 2017, especialmente os acontecidos en Portugal, mostra como conclusión a chegada da tipoloxía potencial de incendios de sexta xeración, letais para a poboación, os servizos de defensa contra incendios, as infraestruturas e os intereses da sociedade en xeral.

Os grandes incendios forestais que afectan extensas áreas homoxéneas nas que existe unha alta carga de combustible tras o abandono da agricultura e a silvicultura acaban retroalimentando o abandono e o risco de sufrir un novo grande incendio é maior. 
Para anticiparse ás situacións de perturbación causadas polo lume, a acción silvícola é fundamental e, en xeral, terá sempre unha certa compoñente preventiva no seu obxectivo de xestión e mellora das masas forestais.

O tipo de material combustible e as súas características físicas e químicas, a cantidade "carga» del, a súa superficie de exposición, o seu grao de compactidade e a súa distribución espacial nos planos horizontal e vertical son os factores que determinarán o comportamento do lume. Os combustibles son complexos en moi alto grao nas súas características e interaccións. En circunstancias normais, mesmo por riba da súa composición específica, a estrutura da masa é o principal condicionante da súa inflamabilidade a escala de poboamento forestal e paisaxe.

Basicamente, a aplicación da silvicultura preventiva pódese realizar en dous niveis territoriais: así, diferéncianse estratexias a escala local (parcela, monte ou grupo de montes) e a escala comarcal. As principais accións previstas pola silvicultura preventiva son actuacións sobre o combustible forestal, creación de descontinuidades na masa e nas infraestruturas lineais e prevención a escala comarcal, con modificación do combustible a escala de paisaxe.

En xeral, a prevención estrutural non segue unha política transversal, encarando o territorio como un todo, e adoita considerarse como a suma de accións, a escalas de xestión forestal, que son executadas por diferentes axentes e organismos. A pesar de poder ser eficaz nos casos máis habituais de incendios, esta falta de accións xeneralizadas en territorios máis amplos non permite unha adecuada defensa fronte aos grandes incendios forestais.

En Galicia, o territorio é o resultado de milleiros de anos de intervención humana. Actualmente as mudanzas prodúcense cunha grande intensidade e rapidez e, na maioría dos casos, sen integración entre elas. A expansión da denominada interface urbano-forestal, asociada á crecente dispersión do sistema de asentamentos e á progresión da vexetación natural, constitúe unha dinámica territorial preocupante.

Despois de máis de trinta anos de autonomía galega, a ordenación do territorio mantense como unha materia pendente. A manifesta dificultade amosada durante décadas para planificar o crecemento ordenado do urbanismo galego fai dubidar de que os instrumentos inspirados na mesma filosofía, a da planificación urbanística, sexan axeitados para traballar na ordenación do espazo rural e, en particular, do forestal. 
A propia «delimitación» do que se entende por espazo forestal no territorio non é un asunto trivial, nin sequera desde o punto de vista xurídico.

Por outra banda, o mesmo concepto de ordenación forestal veu experimentando un profundo cambio, grazas á experiencia acumulada de máis dun século desde a súa concepción e aplicación, con discutible grao de implantación. No que atinxe á xestión de propietarios forestais particulares, permaneceu durante o último século á marxe dela, por complexa e por afastada da ortodoxia da ordenación de montes.

Noutros países, en xeral, a planificación en montes privados enténdese como unha ferramenta de axuda ao silvicultor na que se pon en xogo a información que producen ou posúen os organismos públicos forestais. Os traballos de inventario que debe sufragar o propietario forestal dependen do seu mero interese en obter máis coñecementos e cuantificacións sobre o estado do seu monte. Desde o punto de vista do interese público, búscase que os plans sirvan para que os propietarios forestais coñezan e apliquen as restricións legais sobre áreas de conservación e demais elementos.

Neste sentido, o desafío principal é entender, prioritariamente, a "ordenación forestal» como a organización no espazo e no tempo da silvicultura, e que pase a ser sempre un conxunto de compromisos bidireccionais, entre a propiedade e a sociedade (representada, na maior parte das ocasións, pola Administración competente), ao respecto das liñas xerais de xestión que desenvolver nunha propiedade específica.

Deste xeito, é en extremo interesante o camiño emprendido pola Lei 7/2012, do 28 de xuño, de montes de Galicia e, con posterioridade, o Decreto 52/2014, do 16 de abril, polo que se regulan as instrucións xerais de ordenación e de xestión de montes de Galicia.

Como a maior parte das unidades de xestión forestal posúen un escaso tamaño e algunhas das principais medidas preventivas de incendios forestais descritas en apartados anteriores han de deseñarse e executarse a unha escala de "paisaxe», unha escala interesante de traballo é aquela superior á da unidade de xestión e inferior á comarcal.

Todas estas disposicións apuntan ao decisivo papel que PPDCIFD e PORF deberían ter na execución de medidas preventivas en escalas superiores á da unidade de xestión forestal. A realidade, hoxe en día, non indica o mesmo. 
Non parece que esteamos carentes de ferramentas legais de regulación e planificación do espazo forestal, senón máis ben ao contrario. Así, todo apunta a unha excesiva proliferación normativa, de difícil encaixe e arrevesada xerarquía.

Cando se producen episodios graves de incendios, con frecuencia esquécese que os silvicultores e comunidades de montes son grandes afectados polos lumes e como tales merecen ser tratados.

Nun territorio maioritariamente privado, onde a xestión directa, ao contrario que noutras áreas xeográficas, non corresponde aos poderes públicos, a misión da política forestal é a de servir de marco e, á vez, de panca para posibilitar a mellora da xestión de miles de axentes, compatibilizándoa coa defensa do interese xeral.

A falta de rendibilidade de moitos modelos forestais e os cambios experimentados no mundo rural durante os últimos vinte anos levan consigo o incremento da superficie forestal infraxestionada ou mesmo abandonada. Isto, ademais das obvias consecuencias desde o punto de vista produtivo, incrementa o risco de maiores e máis graves incendios, sobre todo nas áreas de interface urbano-forestal.

Tendo en conta a modesta rendibilidade de moitas das alternativas forestais e a non-profesionalidade da maior parte dos silvicultores, non é estraño que os procesos de incremento da presión normativa ou impositiva se traduzan, ao contrario do que pretenden, en incrementos da superficie infraxestionada ou abandonada.

No proceso de abandono, gradualmente vaise pasando por diversos estados intermedios, até chegar ao denominado abandono irreversible, no cal territorio e propietario perden calquera vencello.

Cando falamos de silvicultura preventiva a escala de paisaxe, debería empregarse a intervención pública sobre as áreas de abandono irreversible para desenvolver estratexias preventivas.

Do mesmo xeito, para frear o proceso de abandono no territorio, antes (ou ademais) da toma de medidas ambiciosas para a reversión, debería evitarse que o proceso seguise producíndose.

Cando se analizan os silvicultores activos, non é factible establecer de xeito nidio unha liña que separe a xestión forestal «correcta» da que non o é. A multiplicidade de posibles itinerarios silvícolas e os distintos valores que chegan a alcanzar as variables que poderían representar esa xestión obrigan a considerar a 
«bondade» da xestión forestal como un continuo, no cal normalmente é fácil distinguir os extremos, pero a gradación intermedia é, en moitos aspectos, sutil. Semella clave a segmentación dos xestores para a aplicación de medidas distintas. O emprego segmentado dun abano de accións (desde as medidas coercitivas aos incentivos, pasando pola extensión forestal) tería como obxectivo mellorar, de xeito constante, a xestión forestal en Galicia e, con isto, a prevención dos incendios que, en número, extensión e intensidade, poidan supoñer danos e riscos como os vividos en 2017.

Unha parte da responsabilidade de evitar a reiteración de incendios catastróficos reside en decisións que cada compoñente da sociedade toma todos os días e que inflúen no territorio: onde e como se vive; que se consome; onde foi producido iso que se consome; se se está ou non disposto a pagar polo lecer que se desenvolve en áreas forestais, ou polo osíxeno ou a auga que producen; que se esixe aos representantes políticos; se se participa na comunidade de montes onde se reside; se se están buscando alternativas para pór en produción as parcelas forestais que se herdaron. Hai tarefa para todos antes dos incendios. 


\section{REFERENCIAS BIBLIOGRÁFICAS}

Ávalos, I. (2017): Ejemplo de gestión de un patrimonio rural familiar según la Ley 7/2012 de Montes de Galicia, traballo de fin de grao inédito (dir. J. Picos), Escola de Enxeñaría Forestal de Pontevedra (Universidade de Vigo).

CASTELlnou, MarC / ANTONI Rifà (2007): «El modelo de extinción de incendios forestales catalán», en IV Conferencia Internacional sobre Incendios Forestales (Wildfire 2007), Sevilla (España).

Castellnou, Marc / Marta Miralles (2008): "Generaciones de incendios: herramienta de clasificación del riesgo y de las necesidades estratégicas en su gestión», DGPEIS, comunicación interna.

Chas-Amil, María L. / Julia Touza / Eduardo García-Martínez (2013): «Forest fires in the wildland-urban interface: A spatial analysis of forest fragmentation and human impacts», Applied Geography, 43, 127-137.

Confemadera Hábitat Galicia (2014): Informe de resultados 2013, [Santiago de Compostela].

Corbelle Rico, Eduardo / Rafael CRECEnTE MASEDA (2008): «El abandono de tierras: concepto teórico y consecuencias", Revista Galega de Economia, 17:2, 1-15.

Corbelle Rico, Eduardo / Rafael Crecente Maseda (2014): «Urbanización, forestación y abandono. Cambios recientes en el paisaje de Galicia, 1985-2005", Revista Galega de Economía, 23:1, 35-52.

EID, Tron (2006): «Forest Planning in Private Forests - Norway», en Tuula Nuutinen / Leena Kärkkäinen / Leena Kettunen (eds.), Forest Planning in Private Forests in Finland, Iceland, Norway, Scotland and Sweden. Proceedings of ELAV seminar, 23-24 March 2006, Koli, Finland. Working papers of the Finnish Forest Research Institute, 38, 36-41.

FAO (Organización de las Naciones Unidas para la Alimentación y la Agricultura) (1996): Informe de la $5^{a}$ Conferencia Regional para Europa, Sevilla (España), 5-11 de octubre de 1966, Roma.

FARRIOL I ALMIRALL, Ricard (2008): «Instrumentos y métodos de planificación forestal en montes privados de Catalunya: los planes técnicos de gestión y mejora forestal», Cuadernos de la Sociedad Española de Ciencias Forestales, 27: «Actas de la Reunión sobre ordenación por rodales: experiencias y aplicación», $35-42$.

FERNANDES, Paulo M. (2009): «Fuel management and fuel treatments: 1. Introduction: background and rationale», Forest fires: impacts and post-fire management, 13-18 April 2009, Antalya, Turkey.

Fernandes, Paulo M. / Tiago Monteiro-Henriques / Nuno Guiomar / Carlos Loureiro / Ana M. G. BARros (2016): «Bottom-Up Variables Govern Large-Fire Size in Portugal», Ecosystems, 19:8, 1362-1375.

GARITACELAYA SALDISE, Jesús (2008): «La sorprendente historia de cómo se disiparon y desvanecieron los métodos de ordenación de montes", Cuadernos de la Sociedad Española de Ciencias Forestales, 27: "Actas de la Reunión sobre ordenación por rodales: experiencias y aplicación», 95-102.

GONDAR PORTASANY, Marcial (2007): «Territorio e identidade: proposta para unha nova filosofía dos parques empresariais", Foro do Instituto de Estudos das Identidades Territorio, paisaxe e identidade, Santiago de Compostela, Museo do Pobo Galego, 28-36.

González Molina, José María / Miriam Piqué Nicolau / Pau Vericat Grau (2006): Manual de ordenación por rodales: gestión multifuncional de los espacios forestales, Solsona, Centre Tecnològic Forestal de Catalunya. 
LÓPEZ IgLeSIAS, Edelmiro (2018): «Desestruturación do medio rural e desorde do territorio: o pano de fondo do problema dos incendios forestais en Galicia», Coloquio Galaico-Portugués sobre Incendios Forestais: Unha nova xeración de lumes?, Santiago de Compostela, Consello da Cultura Galega.

MAdrigal, Alberto (1998): «Problemática de la ordenación de masas artificiales en España», Cuadernos de la Sociedad Española de Ciencias Forestales, 6: «II Reunión sobre Ordenación de Montes», 13-20.

NuUtinen, Tuula (2006): «Forest Planning in Private Forests in Finland», en Tuula Nuutinen / Leena Kärkkäinen / Leena Kettunen (eds.), Forest Planning in Private Forests in Finland, Iceland, Norway, Scotland and Sweden. Proceedings of ELAV seminar, 23-24 March 2006, Koli, Finland. Working papers of the Finnish Forest Research Institute, 38, 28-31.

Oliveira, Emanuel (2016): La Prevención a la Escala del Paisaje para hacer frente a los Grandes Incendios Forestales. Análisis en el Alto Minho. Portugal, traballo de fin de mestrado (dir. Rosa Planelles), ETSI Montes, Forestal y del Medio Natural (Universidad Politécnica de Madrid).

PICOS MARTín, Juan (2015): O sector forestal en Galicia: problemática actual e perspectivas futuras, Documento 10/2015, Foro Económico de Galicia, s. 1 .

Picos Martín, Juan / Marc Castellnou Ribau / António Joaquim Salgueiro Rocha da Silva (2018): Cooperación transfronteriza en la prevención y extinción de incendios forestales en el Eixo Atlántico, Eixo Atlántico do Noroeste Peninsular, s. 1. (Cuadernos de Cooperación del Eixo Atlántico).

PIcos, Juan (coord.) (2018): La Cadena Forestal-Madera de Galicia 2017, Axencia Galega da Industria Forestal, Consellería de Economía e Industria, Xunta de Galicia / Universidade de Vigo.

Pyne, Stephen J. / Patricia L. ANDREWs / Richard D. LAVEN ( $\left.{ }^{2} 1996\right)$ : Introduction to Wildland Fire, New York, NY, John Wiley and Sons.

Rojo, Alberto / Santos G. Arenas / Guillermo Riesco (1998): «Ordenación de montes en Galicia», Cuadernos de la Sociedad Española de Ciencias Forestales, 6: «II Reunión sobre Ordenación de Montes», 177-189.

SAURA MARTínez DE TODA, Santiago (2009): «Del rodal al paisaje: un cambio de escala, nuevas perspectivas para la planificación y ordenación forestal», 50 Congreso Forestal Español: Montes y sociedad: Saber qué hacer, Ávila, 21-25 de septiembre, Sociedad Española de Ciencias Forestales / Junta de Castilla y León.

Sociedad Española de Ciencias Forestales (SECF) (2008): «Conclusiones de la reunión del grupo de trabajo de ordenación de montes de la Sociedad Española de Ciencias Forestales, realizada en Solsona, en los días 28, 29 y 30 de noviembre de 2007», Cuadernos de la Sociedad Española de Ciencias Forestales, 27: «Actas de la Reunión sobre ordenación por rodales: experiencias y aplicación», 149-150.

VÉLEZ, Ricardo (coord.) (2000): La defensa contra incendios forestales: fundamentos y experiencias, Madrid, McGraw-Hill.

Wilhelmsson, Erik (2006): «Forest Management Planning for Private Forest Owners in Sweden», en Tuula Nuutinen / Leena Kärkkäinen / Leena Kettunen (eds.), Forest Planning in Private Forests in Finland, Iceland, Norway, Scotland and Sweden. Proceedings of ELAV seminar, 23-24 March 2006, Koli, Finland. Working papers of the Finnish Forest Research Institute, 38, 52-60. 